Article

\title{
Hydrological Modeling of Climate Change Impacts in a Tropical River Basin: A Case Study of the Cauto River, Cuba
}

\author{
Yalina Montecelos-Zamora ${ }^{1}$ (D), Tereza Cavazos ${ }^{2, *}$, Thomas Kretzschmar ${ }^{1}$, Enrique R. Vivoni ${ }^{3}$ (D), \\ Gerald Corzo $^{4}$ and Eugenio Molina-Navarro 5 (iD \\ 1 Departamento de Geología, Centro de Investigación Científica y de Educación Superior de \\ Ensenada (CICESE),Ensenada 22860, Mexico; ymontece@cicese.edu.mx (Y.M.-Z.); tkretzsc@cicese.mx (T.K.) \\ 2 Departamento de Oceanografía Física, Centro de Investigación Científica y de Educación Superior de \\ Ensenada (CICESE), Ensenada 22860, Mexico \\ 3 School of Earth and Space Exploration \& School of Sustainable Engineering and the Built Environment, \\ Arizona State University, Tempe, AZ 85287, USA; vivoni@asu.edu \\ 4 Department of Integrated Water Systems and Governance, UNESCO-IHE Institute for Water Education, \\ 2611 Delft, The Netherlands; g.corzo@un-ihe.org \\ 5 Department of Bioscience, Aarhus University, 8600 Silkeborg, Denmark; eugenio.molinanavarro@gmail.com \\ * Correspondence: tcavazos@cicese.mx; Tel.: +52-646-175-0500 (ext. 24049)
}

Received: 17 July 2018; Accepted: 22 August 2018; Published: 25 August 2018

\begin{abstract}
The soil and water assessment tool (SWAT) model was applied for the first time in Cuba to assess the potential impacts of climate change on water availability in the Cauto River basin. The model was calibrated (and validated) for the 2001-2006 (2007-2010) period at a monthly timescale in two subbasins La Fuente and Las Coloradas, representative of middle and upper sections of the Cauto basin; the calibrated models showed good performance. The output available for the regional climate Model RegCM4.3 was used to force the calibrated SWAT models to simulate a baseline (1970-2000) period and near-future (2015-2039) hydrologic regimes under the representative concentration pathway (RCP) 8.5 emission scenario. The future projections suggest regional increases of $1.5^{\circ} \mathrm{C}$ in mean annual temperature and a $38 \%$ decrease in mean annual precipitation in the subbasins. These changes translate to possible reductions in the annual streamflow of up to $61 \%$ with respect to the baseline period, whereas the aquifer recharge in the basin is expected to decrease up to $58 \%$, with a consequent reduction of groundwater flow, especially during the boreal summer wet season. These projection scenarios should be of interest to water resources managers in tropical regions.
\end{abstract}

Keywords: rainfall-runoff modeling; SWAT; RegCM4.3; Cuba; climate change; water management

\section{Introduction}

The management and planning of water resources is becoming more challenging due to the uncertainties of climate change [1]. The increase in temperature, variations in precipitation, and changes in the frequency of extreme events increase the probability of flood occurrences and change the total and seasonal water supply, among other impacts [2]. Recent studies on climate change in the Caribbean $[3,4]$, particularly in Cuba [5,6], suggest that air temperatures may increase, and precipitation may decrease at the end of the 21st century, especially during the summer season. This, combined with changes in land use, could have an important impact on hydrological processes at the basin level.

Modeling the hydrology of Caribbean river basins presents challenges due to their high climatic variability and the strong influence of extreme events, for instance by tropical storms and hurricanes [7]. Despite the increasing availability of hydrological models, their use in tropical islands is generally 
limited [8]. Understanding the impacts of climate change in this region is critical for designing adaptation strategies for flood and drought protection and sustainable water resources management.

A properly calibrated hydrological model can provide useful information for the management and planning of water resources. Some models allow quantifying the impacts of climate change on water resources through the simulation of hydrological processes $[9,10]$. Hydrological models combined with climate change scenarios generated by general circulation models (GCMs) $[11,12]$ or regional climate models (RCMs) [13] are commonly used. However, this combined approach has not been used yet in Cuba, at least not in peer-reviewed literature. On the other hand, climate change has been extensively studied in Cuba and the Caribbean region using GCMs and RCMs, such as RegCM4.3 [14,15] and PRECIS [16].

There are several hydrological models suitable for estimating current water availability, such as the Hydrologic Simulation Package-FORTRAN (HSPF), the Chemicals, Runoff, and Erosion from Agricultural Management Systems (CREAMS), the Hydrologic Engineering Center-Hydrologic Modeling System (HEC-HMS), and the Soil and Water Assessment Tool (SWAT). In particular, SWAT has been widely used in many regions of the world and for different purposes, such as water resource predictions and the impact of climate change on the water balance components (i.e., Faramarzi et al. [17] in Africa; Trang et al. [18] in East Asia; Anand et al. [19] in South Asia; Shrestha et al. [20] in North America; Molina-Navarro et al. [21] in Mexico; Leta et al. [22] in the Pacific, and Abbaspour et al. [23] in Europe).

Hydrological modeling applications using SWAT in Cuba are scarce, and the few works published in the western region of the country are not related to the objectives of the current study. For example, Sánchez [24] used SWAT in the Bay of Cienfuegos to determine erosive potential, and Mesa [25] used the model to analyze the effect of pollutants on a reservoir in Mayabeque. Other hydrological models have been used in the country as well (i.e., HEC-HMS) for various purposes, including simulation of extreme events such as flood forecasting [26,27]. While these studies focused on hydrological applications, the novelty of our study is the assessment of the possible impacts of climate change on water resources in the Cauto river basin using a combination of two models (SWAT and RegCM4.3).

Precipitation in Cuba has a high interannual and seasonal variability, characterized by summer rainfall and relatively dry winters. Seasonally, Cuba is affected by convective storms and tropical cyclones in summer and autumn, which are partially modulated by the El Niño-Southern Oscillation (ENSO) at interannual timescales [6]. The variability of these phenomena generates alternations of rainy years and prolonged droughts. Recent studies have shown that precipitation over Cuba is expected to decrease during the wet season (May-October) and to increase during the dry season (November-April) [5,6]. Given that approximately $70 \%$ of the annual rainfall occurs during the wet season, the expected reduction in annual rainfall may lead to a decline in the components of the hydrologic cycle. The implications of these possible changes are of regional interest, in particular for managers who might need to adapt operations and infrastructure according to variations in precipitation and streamflow regimes.

This situation is particularly severe in Cuba's largest watershed, the Cauto River (Figure 1), where $10 \%$ of the population lives. Additionally, water resources in the basin have been under pressure due to increased demands for irrigation, because agriculture is the primary land use in the Cauto River basin [28]. On the other hand, recurrent flooding and droughts, shortage of water supply, landslides, and soil erosion have already been documented for the basin [28]. Thus, management tools accounting for climate change simulations and hydrological processes are invaluable for planning the future of hydrological resources in this tropical region.

The use of hydrological models coupled with RCMs within this tropical basin would help quantify the potential changes in hydrological dynamics induced by climate change projections, as it has been done in other basins of the world (i.e., Jha et al. [13] in the Mississippi River; Shrestha et al. [29] in the Mekong River; Perra et al. [30] in a Mediterranean basin). Furthermore, near future climate change scenarios and their impacts on the regional hydrology are very relevant for national adaptation 
strategies and water resources management in the basin. The period of 2015-2039 is strategic for Cuba in the context of its intended nationally determined contributions (INDCs) [31] under the Paris Agreement. Moreover, in the near future (2015-2039), three greenhouse gas emission scenarios (Representative concentration pathways RCP, 4.5, 6.5, and 8.5) follow a similar path of increment; after that period, uncertainties increase over time due to the various emission scenarios and other factors [32]. Thus, projections based on the high RCP 8.5 emission scenario are used here to assess near-future changes in the hydrology of the Cauto River basin.

In this study, we carried out for the first time in Cuba regional hydro-climatic projections in two subbasins of the Cauto River basin. The goal was to understand how climate change will affect the availability of the water components in this tropical basin in the near future (2015-2039 with respect to the 1970-2000 baseline period) under the RCP 8.5 emission scenario. We addressed this challenge through the use of a set of regional modeling tools (SWAT and RegCM4) and long-term data sets, as described in Section 2. Section 3 shows the results of the calibration and validation of the SWAT model and its capacity to simulate the observed water resources in the upper and middle parts of the Cauto River basin (in Las Coloradas and La Fuente subbasins, respectively). After the SWAT calibration, output available from the RegCM4.3 regional climate model [33] was used to force the hydrologic model to determine the possible effects of climate change on streamflow and other water balance components in the near future relative to the baseline period. The discussion of the results and the main conclusions of this work are presented in Sections 4 and 5, respectively.

\section{Materials and Methods}

\subsection{Study Area}

The Cauto River basin, the largest in Cuba, covers a surface area of $9540 \mathrm{~km}^{2}$; the river is also the country's longest, with a length of $343 \mathrm{~km}$ (Figure 1). The climate of this basin is characterized by a rainy season (May-October) and a dry season (November-April), with average rainfall of $1260 \mathrm{~mm} /$ year. As a result, the flow is seasonal, with higher flows during the summer and an average annual flow of $63 \mathrm{~m}^{3} / \mathrm{s}$ (Table 1). The Cauto River flows through 4 out of the 5 provinces of southeast Cuba until it drains into the Caribbean Sea (Figure 1). Agriculture is the main economic activity; crops predominate in the Cauto River valley, whereas evergreen forests cover the upper part of the basin (Figure 2a). This study is focused on the results of two subbasins (La Fuente and Las Coloradas) located in the middle and upper parts of the basin (Figure 1). Both subbasins play an important role in the streamflow (discharge) management in the basin, especially during the rainy season; these subbasins were also selected because of the availability of observed streamflow and climate data, which are essential for the calibration and validation of the hydrological model.

La Fuente subbasin is in the mid-altitude region; it has an elevation between 120 and 500 m.a.s.l. and an area of $75 \mathrm{~km}^{2}$, while Las Coloradas is in the upper-altitude region between 500 and 1000 m.a.s.l. with an area of $64 \mathrm{~km}^{2}$ (Table 1). In the two subbasins, there are no dams (Figure 1). These subbasins have a rainy season from May to October and a dry season from November to April, with an average annual rainfall of $1625 \mathrm{~mm} / \mathrm{yr}$ in La Fuente and $1447 \mathrm{~mm} /$ year in the Las Coloradas. The average monthly temperature ranges from 19 to $21^{\circ} \mathrm{C}$ [34]. According to the Instituto de Planificación Física of Cuba [28], the soil types in both subbasins are characterized by fersialitic, ferralitic, and brown soils with carbonates (Figure $2 b$ ). 


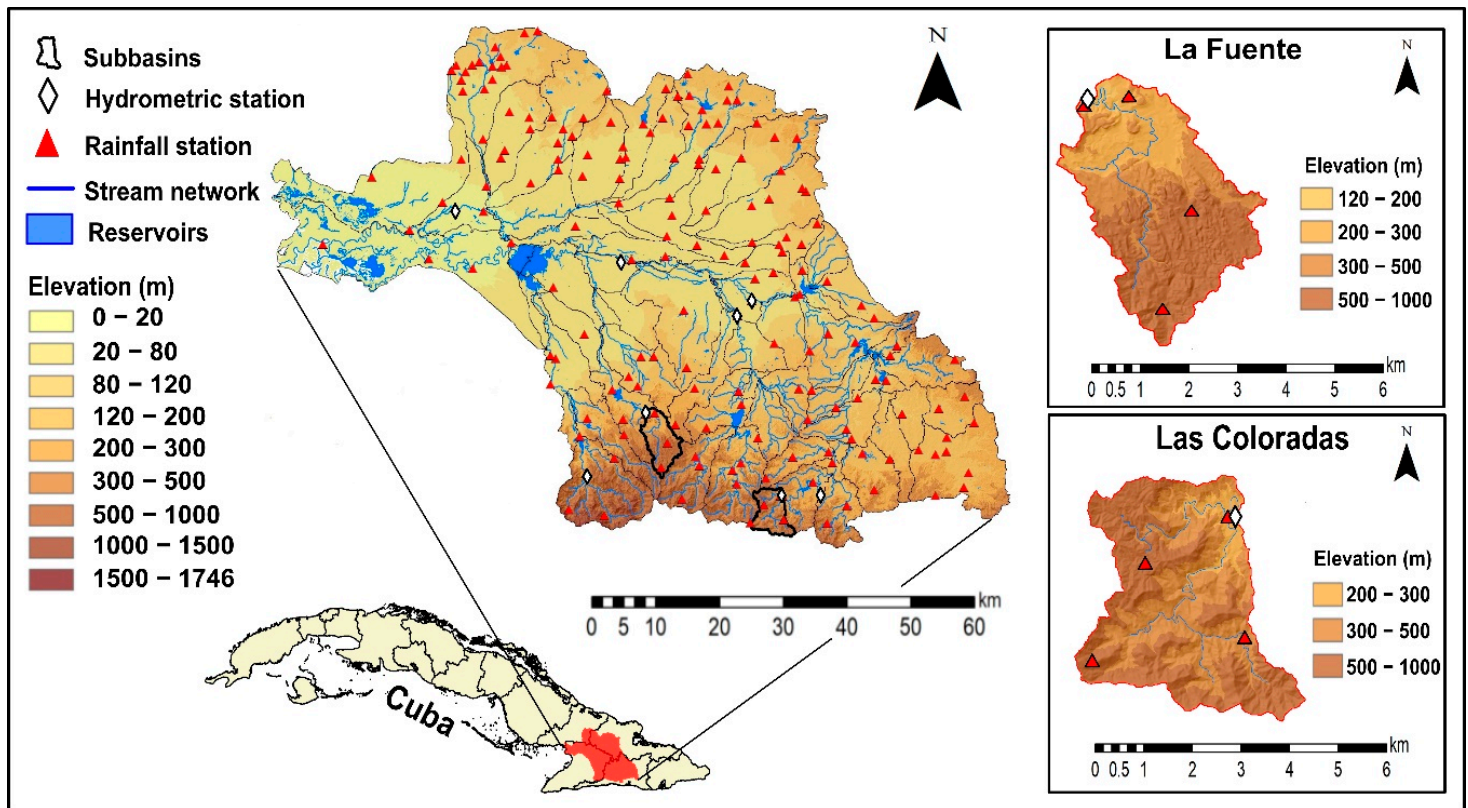

Figure 1. Cauto River basin in southeast Cuba with the location of climate and hydrometric stations, streams, and topography. The two subbasins (La Fuente and Las Coloradas) are identified with more detail on the right panels.

Table 1. Characteristics of the Cauto River basin and two of its subbasins for the 1970-2010 period.

\begin{tabular}{|c|c|c|c|c|c|c|c|c|c|}
\hline \multirow[b]{2}{*}{ Basin } & \multirow{2}{*}{$\begin{array}{l}\text { Area } \\
\left(\mathbf{k m}^{2}\right)\end{array}$} & \multirow{2}{*}{$\begin{array}{c}\text { Range of } \\
\text { Elevation (m) }\end{array}$} & \multicolumn{3}{|c|}{ Precipitation (mm) } & \multicolumn{3}{|c|}{ Mean Discharge $\left(\mathrm{m}^{3} / \mathrm{s}\right)$} & \multirow{2}{*}{$\frac{\text { Tmean }\left({ }^{\circ} \mathrm{C}\right)}{\text { Annual }}$} \\
\hline & & & Annual & $\begin{array}{c}\text { Wet } \\
\text { Season }\end{array}$ & $\begin{array}{l}\text { Dry } \\
\text { Season }\end{array}$ & Annual & $\begin{array}{c}\text { Wet } \\
\text { Season }\end{array}$ & $\begin{array}{c}\text { Dry } \\
\text { Season }\end{array}$ & \\
\hline Cauto & 9540 & $0-1753$ & 1232 & 904 & 328 & 63 & - & - & 27 \\
\hline La Fuente & 75 & $120-500$ & 1625 & 1038 & 590 & 16.9 & 13.38 & 7.65 & 21 \\
\hline Las Coloradas & 64 & 500-1000 & 1447 & 993 & 453 & 10.8 & 7.70 & 3.86 & 24 \\
\hline
\end{tabular}

\subsection{Hydrological Model Description}

\subsubsection{Hydrological Model Description}

SWAT is a hydrological model of public domain used to simulate the quality and quantity of surface and ground water for different climate regimes and to predict the potential impacts of climate change on water resources [35]. The model is based on the general water balance Equation (1), described by Neitsch et al. [36], which is used to simulate different hydrological processes.

$$
S W_{t}=S W_{0}+\sum_{i=1}^{t}\left(R_{\text {day }}-Q_{\text {surf }}-E_{a}-W_{\text {seep }}-Q_{g w}\right)
$$

where $S W_{t}$ and $S W_{0}$ are the final and initial soil water contents $(\mathrm{mm}), t$ is time (days), $R_{\text {day }}$ is the amount of precipitation (mm), $Q_{\text {surf }}$ is the amount of surface runoff $(\mathrm{mm}), E_{a}$ is the amount of evaporation $(\mathrm{mm}), W_{\text {seep }}$ is the amount of percolation and bypass flow exiting the soil profile bottom (mm), and $Q_{g w}$ is the amount of return flow ( $\mathrm{mm})$.

The SWAT theoretical documentation version 2011 [36] describes the main components of the model: (a) surface runoff is estimated using the Soil Conservation Service (SCS) curve number (CN) method [37]; (b) the rate and velocity of overland flow and a variable storage routing method [38] in the channel network is obtained using Manning's equation; and (c) the lateral flow is simulated using a kinematic storage model [39], whereas the return flow considers an unconfined aquifer [36]. 
SWAT includes several options to estimate potential evapotranspiration; in the current study, the Hargreaves method [40] was employed.

\subsubsection{Data Input and Model Setup}

The watershed delineation of the drainage network and the limits of the subbasins were obtained using ArcSWAT version 2012 [41] and a digital elevation model (DEM) with a resolution of $25 \mathrm{~m} \times 25 \mathrm{~m}$. The DEM was obtained from the studies of Agencia de Medio Ambiente [42]. For this purpose, the river network for the Cauto basin was extracted using standard analytical techniques contained in the ArcSWAT GIS interface (a minimum upstream contributing area of $80 \mathrm{~km}^{2}$ was used as a threshold value for defining river cells). A total of 82 subbasins were obtained for the Cauto River basin. They have similar size and represent the heterogeneity of the catchment area (Figure 1). Our focus in this modeling effort using SWAT was on two subbasins La Fuente and Las Coloradas, where the variability of terrain, soil, and land use conditions is lower than in the entire Cauto River basin.

The land use and soil type information shown in Figure 2 was obtained from the cartography generated by the Cuban Soils Institute (scale 1:100,000). Seven types of land use were identified in the basin (Figure 2a), with being agriculture the most predominant (39\%). The remaining areas are covered by forest and pasture (33\%) and mixed forests with evergreen vegetation (18\%). In particular, the subbasins modeled in this study (Figure 1) are mainly covered by forest and pasture.

Because SWAT only contains a database of soil types for the United States, it was necessary to implement a soil database for the Cauto River basin. The World Reference Base for Soil Resources [43] was used to identify the soil properties, similar to other works [21]. The predominant soil types in the basin (Figure $2 \mathrm{~b}$ ) are brown (33\%), vertisols (24\%), and fluvisol (10\%). For model input, the terrain slopes derived from the DEM were divided into three major classes, following the Food and Agriculture Organization (FAO) criteria $0-8 \%, 8-30 \%$, and $>30 \%$ [43] to capture the major physiographic differences in the basin. Slopes lower than $8 \%$ lead to rill and inter-rill erosion, slopes between 8 and $30 \%$ lead to gully erosion, and when slopes are higher than 30\%, stream and channel erosion processes start.

Based on the combination of land use, soil types, and slope data, the model was subdivided into small areas known as hydrological response units (HRUs). A minimum threshold of $10 \%$ was used to eliminate minor land uses, soils, and slopes in each subbasin to facilitate processing and to limit the number of HRUs in each subbasin.

Meteorological and streamflow data were provided by the Instituto de Meteorología de Cuba (INSMET) and the Grupo Empresarial de Aprovechamiento de los Recursos Hidráulicos (GEARH). The monthly streamflows for two hydrometric stations (one in each subbasin) were obtained for 2001-2010. Daily precipitation and maximum and minimum temperatures from stations in the basin were obtained for the period from 1996 to 2010 (Figure 1). Missing meteorological data were completed through a linear regression method, using the nearby stations data. All regression analyses were statistically significant $(p \leq 0.05)$, showing a good correlation between stations. 


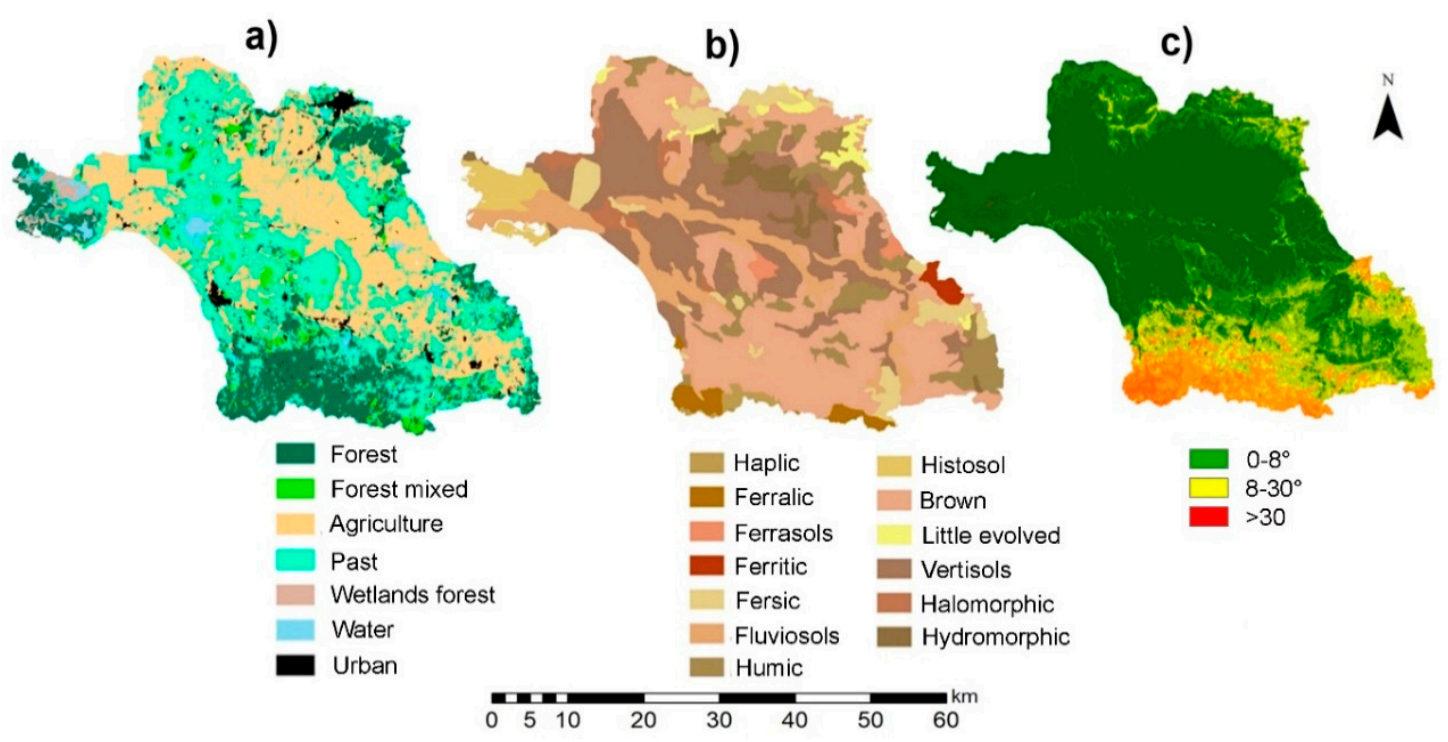

Figure 2. Physical characteristics of the Cauto River basin: (a) land uses, (b) soil types, and (c) slopes.

\subsubsection{Model Calibration and Validation}

Given the streamflow data availability (on a monthly basis) in the two subbasins, a simulation period from 1 January 1996 to 31 December 2010 was selected. The first five years were used for model spinup (a period that does not necessarily need streamflow data): The calibration period extended from 1 January 2001 to 31 December 2006, and a split-sample validation was performed from 1 January 2007 to 31 December 2010. To evaluate the model simulations under different climate conditions, the calibration and validation periods included wet, average, and dry seasons.

The selection of the 17 initial model parameters and their ranges (Table 2) was based on the basin characteristics, preliminary model runs, and a literature review [23,44]. During the calibration stage, a sensitivity analysis was carried out with the Latin hypercube one-factor-at-a-time (LH-OAT) method [45] to identify the parameters that were most influential in governing streamflow and other hydrological processes. The parameter sensitivity was quantified based on the $p$ value from a Student $t$ test; a parameter was deemed sensitive if $p \leq 0.05$ after running 300 simulations in a single iteration.

Automatic calibration using all 17 parameters was then performed on a monthly timestep using the sequential uncertainty fitting, version 2 (SUFI2) algorithm implemented in the SWAT Calibration and Uncertainty Program (SWAT-CUP) [46]. The SUFI2 method is fast and requires a lower number of model runs to achieve a satisfactory solution compared with other uncertainty analysis techniques [21]. For each subbasin, 1500 simulations were run in three iterations of 500 simulations each, manually readjusting the parameters after each iteration. The "best simulation" was obtained using the difference between observed and simulated streamflow by using the Nash-Sutcliffe efficiency coefficient (NSE) [47] as the objective function.

\subsubsection{Model Performance Metrics}

Model performance was assessed both graphically and statistically using the coefficient of determination $\left(\mathrm{R}^{2}\right), N S E$, and the percent bias (PBIAS), because they are widely used in hydrological calibration and validation [48]. $R^{2}$ varies between 0 and 1 , where 0 indicates a poor fit and 1 a perfect fit. NSE ranges from $-\infty$ to 1 and measures how well the simulated versus the observed data match the 1:1 line [47] as follows:

$$
N S E=1-\left[\frac{\sum_{i=1}^{n}\left(Q^{\text {obs }}-Q^{\text {sim }}\right)^{2}}{\sum_{i=1}^{n}\left(Q^{\text {obs }}-Q^{\text {mean }}\right)^{2}}\right]
$$


where $Q^{o b s}$ and $Q^{\text {sim }}$ are the observed and the simulated data, respectively; $Q^{\text {mean }}$ is the mean value of observations from $i=1$ to $n$ observations. PBIAS is a measure of whether the mean flows simulated by the model $\left(Y^{\text {sim }}\right)$ are larger (positive PBIAS) or smaller (negative PBIAS) than the observations $\left(Y^{o b s}\right)$, indicating over- or underestimation, respectively [48], as follows:

$$
\text { PBIAS }=\left[\frac{\sum_{i=1}^{n}\left(Y_{i}^{\text {sim }}-Y_{i}^{o b s}\right)}{\sum_{i=1}^{n}\left(Y_{i}^{o b s}\right)}\right] \times 100
$$

After analyzing these statistical indicators, we followed the approach of Moriasi et al. [48] to determine the model performance at the monthly time scale: Model simulation is satisfactory if NSE $>0.5$ and if PBIAS $\leq 25 \%$ for streamflow (discharge). However, other authors, such as Van Liew et al. [49] used slightly different criteria for interpreting model performance: An absolute value of PBIAS less than $20 \%$ is considered "good", while values between $\pm 20 \%$ and $\pm 40 \%$ are considered "satisfactory". NSE index values greater than 0.75 are considered "good", and between 0.75 and 0.36 are considered "satisfactory".

\section{3. $\operatorname{Reg} C M 4.3$}

We used the hydrostatic, compressible, three-dimensional, regional climate model RegCM4 [33] originally developed by [50,51]. In 2018, the Abdus Salam International Centre for Theoretical Physics (ICTP) launched the latest version of the RegCM4.7. However, in this work we used RegCM4.3 daily outputs (precipitation, and maximum and minimum temperatures) at 50-km resolution, which are freely available for the Central America domain through the Coordinated Regional Dynamical Experiment (CORDEX) data webpage [33] at (https:/ / esg-dn1.nsc.liu.se/search/cordex/). RegCM4 includes several parameterizations to solve physical, dynamical, and thermodynamic processes. The model output is based on Emanuel [52] convective parameterization over the ocean, the Grell [53] convective scheme over the continent, and the surface module from the community land model version 3.5 [54]. These configurations performed relatively well in Mexico and the Caribbean region at reproducing present-day climate conditions $[15,55,56]$. The initial and lateral boundary conditions for RegCM4.3 were from the Hadley Global Environment Model 2-Earth System (HadGEM2-ES), which reproduces relatively well the Caribbean climate when driving RegCM4 [15,56,57].

Monthly temperature and precipitation data from the climate research unit (CRU) [58] at 50-km resolution, as well as daily temperature and precipitation data from the INSMET-GEARH database from meteorological stations in Cuba were used to evaluate the RegCM4.3 simulations. Daily data of the HadGEM2-ES global circulation model from the Coupled Model Intercomparison Project Phase 5 Experiment (CMIP5) [59] were also used for verification purposes (freely available at http: // cmip-pcmdi.llnl.gov/). Daily data from RegCM4.3 simulations (historical and future projections under the RCP 8.5 emission scenario) without a bias correction were used to force the calibrated SWAT model to simulate present (baseline) and future hydrologic regimes in La Fuente and Las Coloradas subbasins. The future hydrologic changes were obtained by comparing the SWAT projections in the near future (2015-2039) under the RCP 8.5 scenario with respect to the baseline (1970-2000) period.

\section{Results}

\subsection{Modeling Approach}

Table 2 lists the initial ranges of 17 SWAT model parameter values and their final simulated values for each subbasin. The sensitivity analyses showed that five parameters were the most sensitive for the region based on a low $p$-value $(\leq 0.05)$ of a $t$-test: Initial curve number (II) value $(C N 2)$, available water capacity (SOL_AWC), saturated hydraulic conductivity (SOL_K), channel effective hydraulic conductivity (CH_K2), and baseflow alpha factor for bank storage (ALPHA_BNK). Other studies also found these parameters as relevant for hydrological modeling in different basins around the 
world $[60,61]$. The high sensitivity of CN2 and SOL_AWC revealed the importance of the surface runoff in the hydrology of the subbasins, which was expected considering the characteristics of the subbasins. Although the other parameters initially selected in Table 2 showed lower sensitivity, with $p$ values between 0.1 and 0.05 , they were kept in the calibration process due to their importance for groundwater and surface runoff, an argument also emphasized by White and Chaubey [62].

The parameter values estimated by SWAT were within physically reasonable ranges and described the hydrological processes in La Fuente and Las Coloradas according to the precipitation and streamflow observations. The calibrated final values obtained helped identify the differences between the two subbasins. As expected, the curve number $(\mathrm{CN})$ was an important parameter for streamflow production, and the variations between the two subbasins could be attributed to the physical settings. La Fuente subbasin has lower infiltration capacities and higher runoff production potential at mid-elevations as compared with Las Coloradas subbasin. The differences in the soil evaporation compensation factor (ESCO), the baseflow recession coefficient (ALPHA_BF), and the groundwater "revap" coefficient (GW_REVAP) (Table 2) between subbasins can be also linked to physiographic variations.

Table 2. Range of initial values for the adjusted parameters and best-fitted values after calibration with the sequential uncertainty fitting (SUFI2) method for La Fuente and Las Coloradas subbasins. v means that the default parameter is replaced by the best value, and $r$ means the existing parameter's best value varies in a relative range of values. The most sensitive parameters $(p \leq 0.05)$ are shown with an asterisk $\left(^{*}\right)$.

\begin{tabular}{|c|c|c|c|c|c|c|}
\hline \multirow{2}{*}{$\begin{array}{l}\text { Change } \\
\text { Type }\end{array}$} & \multirow[b]{2}{*}{ Parameter } & \multirow[b]{2}{*}{ Description } & \multicolumn{2}{|c|}{ La Fuente } & \multicolumn{2}{|c|}{ Las Coloradas } \\
\hline & & & $\begin{array}{l}\text { Initial } \\
\text { Range }\end{array}$ & $\begin{array}{c}\text { Best } \\
\text { Value }\end{array}$ & $\begin{array}{l}\text { Initial } \\
\text { Range }\end{array}$ & $\begin{array}{c}\text { Best } \\
\text { Value }\end{array}$ \\
\hline $\mathrm{v}$ & ALPHA_BF (days) & -Baseflow recession coefficient & $0-1$ & 0.60 & $0-1$ & 0.20 \\
\hline $\mathrm{v}$ & ALPHA_BNK* & -Baseflow alpha factor for bank storage & $0-1$ & 0.48 & $0-1$ & 0.92 \\
\hline $\mathrm{v}$ & $\mathrm{CH} \_\mathrm{K} 2 *\left(\mathrm{~mm} \mathrm{~h}^{-1}\right)$ & $\begin{array}{l}\text {-Effective hydraulic conductivity in main } \\
\text { channel alluvium }\end{array}$ & $5-130$ & 44.67 & $5-130$ & 77.24 \\
\hline $\mathrm{v}$ & CH_N2 & -Manning's " $n$ " value for the main channel & $0-0.3$ & 0.22 & $0-0.3$ & 0.12 \\
\hline $\mathrm{r}$ & $\mathrm{CN} 2 *$ & -Curve number for soil moisture condition II & $53.9-113.1$ & $54.2-61.3$ & $17.5-113.1$ & $24-83.4$ \\
\hline $\mathrm{v}$ & EPCO & -Plant uptake compensation factor & $0-1$ & 0.78 & $0-1$ & 0.62 \\
\hline $\mathrm{v}$ & ESCO & -Soil evaporation compensation factor & $0-1$ & 0.63 & $0-1$ & 0.28 \\
\hline $\mathrm{v}$ & GW_DELAY (days) & -Delay time for aquifer recharge & $0-500$ & 93 & $0-500$ & 495 \\
\hline $\mathrm{v}$ & GW_REVAP & -Groundwater "revap" coefficient & $0.02-0.2$ & 0.18 & $0.02-0.2$ & 0.16 \\
\hline $\mathrm{v}$ & GWQMN (mm) & $\begin{array}{l}\text {-Threshold water depth in the shallow } \\
\text { aquifer for base flow }\end{array}$ & $0-5000$ & 3414 & $0-5000$ & 3526 \\
\hline $\mathrm{v}$ & Lat_TTIME & -Lateral flow travel time & $0-180$ & 7.2 & $0-180$ & 159.7 \\
\hline $\mathrm{r}$ & OV_N & -Manning's " $n$ " for overland flow & $0.07-0.20$ & $0.09-0.14$ & $0.07-0.20$ & $0.10-0.15$ \\
\hline $\mathrm{v}$ & REVAPMN (mm) & $\begin{array}{l}\text {-Threshold depth of water in the shallow } \\
\text { aquifer for revap to occur }\end{array}$ & 0-1000 & 714 & 0-1000 & 369 \\
\hline $\mathrm{r}$ & $\begin{array}{c}\text { SOL_AWC * } \\
\left(\mathrm{mm} \mathrm{H} \mathrm{H}_{2} \mathrm{O} / \mathrm{mm} \text { soil }\right)\end{array}$ & -Soil available water capacity & $0.1-0.9$ & 0.43 & $0.02-0.9$ & $0.12-0.59$ \\
\hline $\mathrm{r}$ & SOL_BD $\left(\mathrm{g} \mathrm{cm}^{-3}\right)$ & -Moist bulk density & $0.2-4.50$ & $1.47-3.68$ & $0.7-4.0$ & $0.38-0.44$ \\
\hline $\mathrm{r}$ & $\mathrm{SOL} \_\mathrm{K} *\left(\mathrm{~mm} \mathrm{~h}^{-1}\right)$ & -Saturated hydraulic conductivity & $0.9-720$ & $1.80-157.56$ & $3.2-720$ & $1.12-98.56$ \\
\hline $\mathrm{v}$ & SURLAG (days) & -Surface runoff & $0.1-24$ & 23.00 & $0.1-24$ & 2.53 \\
\hline
\end{tabular}

Simulated and observed discharges at the mid-altitude La Fuente subbasin during calibration and validation periods are shown in Figure 3. During calibration, the SWAT simulation reproduced the observed discharges and their variation in time but tended to overestimate the streamflow during dry periods. This overestimation may indicate that the model is not entirely capturing the dynamics of the groundwater components [1] or is not simulating adequately the evapotranspiration capacity of the vegetation [21]. The inaccuracy of the model performance during dry periods may be also associated with the objective function (NSE) used to calibrate the model, which tends to rely more on model performance during flood events [63]. In line with these results, SWAT has been shown to be weak when simulating low flows in other regions [64,65]. 
Model performance metrics for La Fuente and Las Coloradas subbasins are shown in Table 3. For La Fuente subbasin, according to the NSE (=0.67), the calibration is "good" [48] and the validation period is "very good" with an NSE $=0.86$. The PBIAS based on monthly values in La Fuente shows a slight streamflow underestimation $(-4 \%)$ in the calibration and underestimation $(-15 \%)$ during the validation period. The low magnitudes of PBIAS correspond to a "good" performance rating for the model in both periods [48]. The $\mathrm{R}^{2}$ values for discharge are 0.67 for calibration and 0.86 for validation, corresponding to model performance ratings of "good" and "very good", respectively [48]. Although this does not occur frequently, some authors have also reported a statistical improvement in the validation period [66].

Table 3. Performance metric values for monthly calibration and validation of the soil and water assessment tool (SWAT) model in La Fuente and Las Coloradas subbasins.

\begin{tabular}{ccccccc}
\hline \multirow{2}{*}{ Subbasin } & \multicolumn{3}{c}{ Calibration (2001-2006) } & \multicolumn{3}{c}{ Validation (2007-2010) } \\
\cline { 2 - 7 } & NSE & $\mathbf{R}^{\mathbf{2}}$ & PBIAS & NSE & $\mathbf{R}^{\mathbf{2}}$ & PBIAS \\
\hline La Fuente & 0.67 & 0.67 & $-4.0 \%$ & 0.85 & 0.86 & $-15 \%$ \\
Las Coloradas & 0.54 & 0.50 & $19 \%$ & 0.45 & 0.74 & $34 \%$ \\
\hline
\end{tabular}
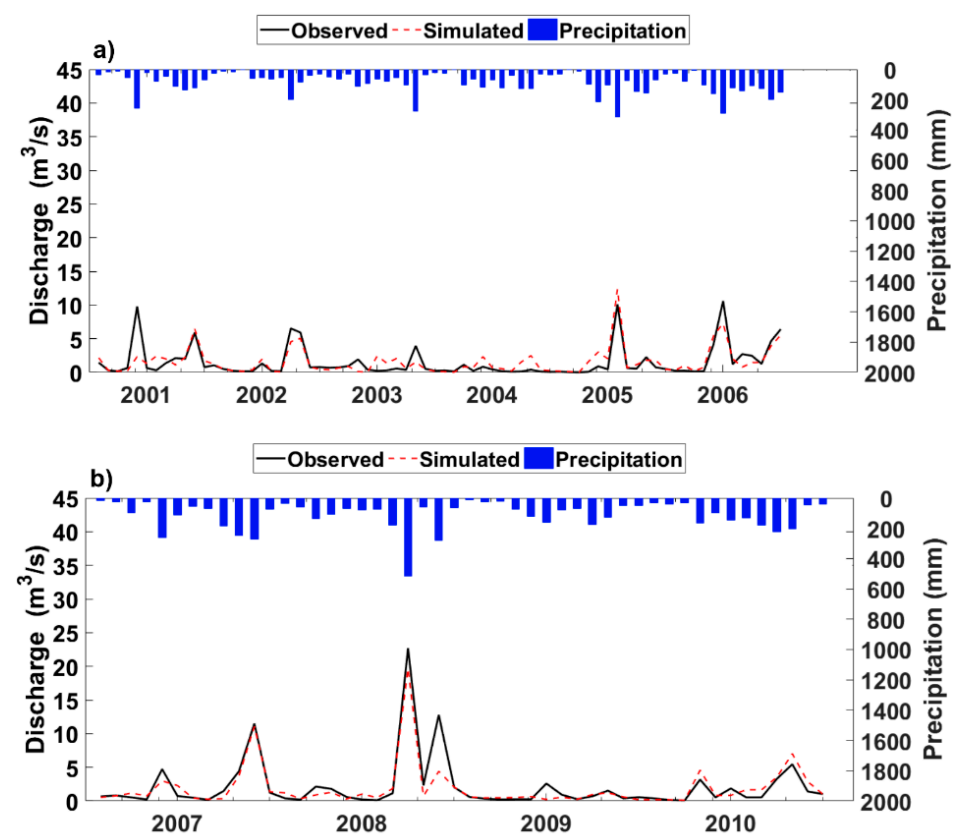

Figure 3. Monthly rainfall and observed and simulated mean monthly discharges during (a) calibration (2001-2006) and (b) validation (2007-2010) periods for La Fuente subbasin.

Figure 4 shows the simulated and observed monthly discharges at the high-altitude Las Coloradas subbasin during the calibration and validation periods. In general, the simulated discharges compared well to the observations, although some of the low flow periods were not well captured, as also noted earlier in La Fuente subbasin (Figure 3). On the other hand, peak flows tended to be overestimated in some extreme precipitation events ( $>500 \mathrm{~mm} / \mathrm{month})$, especially during the validation period (PBIAS 34\%, Table 3). During this period, precipitation was significantly larger (i.e., more than $200 \mathrm{~mm}$ ) (Figure $4 \mathrm{~b}$ ) than the largest two peaks (i.e., $\sim 800 \mathrm{~mm}$ ) of the calibration period (Figure $4 \mathrm{a}$ ). One possible explanation for the overestimation is that the calibration did not cover the most extreme rainfall events of the entire period, resulting in a poor performance during the validation. The overestimation of maximum flows for rainy periods in basins with very rapid hydrological responses has been also reported by some authors in other climates [67]. Consistent with the PBIAS and the monthly skills of NSE (0.54) and $\mathrm{R}^{2}(0.50)$, the performance of the calibration can be described as "satisfactory" [48]. 
During the validation period, the statistical metrics yielded a worse performance than the calibration, as seen in Table 3, but still satisfactory according to Van Liew et al. [49]. It is common for the statistical skill of the validation period to be worse than the calibration period, because the model parameters are optimized for the calibration [48]. In general, the performance over the two subbasins calibration periods ranges from "good" to "satisfactory" according to Moriasi et al. [48] criteria. La Fuente subbasin yielded a better model statistical performance than the Las Coloradas subbasin in all evaluated metrics (higher $\mathrm{R}^{2}$ and NSE and lower absolute PBIAS). Especially noticeable is the better NSE value during validation (0.85 in La Fuente vs. 0.45 in Las Coloradas). The main reason for a worse statistical performance in Las Coloradas may rely on the lack of accuracy in the simulation of most of the flow peaks, while in La Fuente several peaks showed a near-perfect fit. NSE is very sensitive to the accuracy in a high flows simulation, because it tends to rely on the peaks of the calibrated variable [63].

Despite the validation results in the subbasin Las Coloradas, we consider that the calibration model predicts the baseline flow reasonably well; thus, the model is adequate to analyze the future changes in the hydrology of the basin based on climate change scenarios [68].

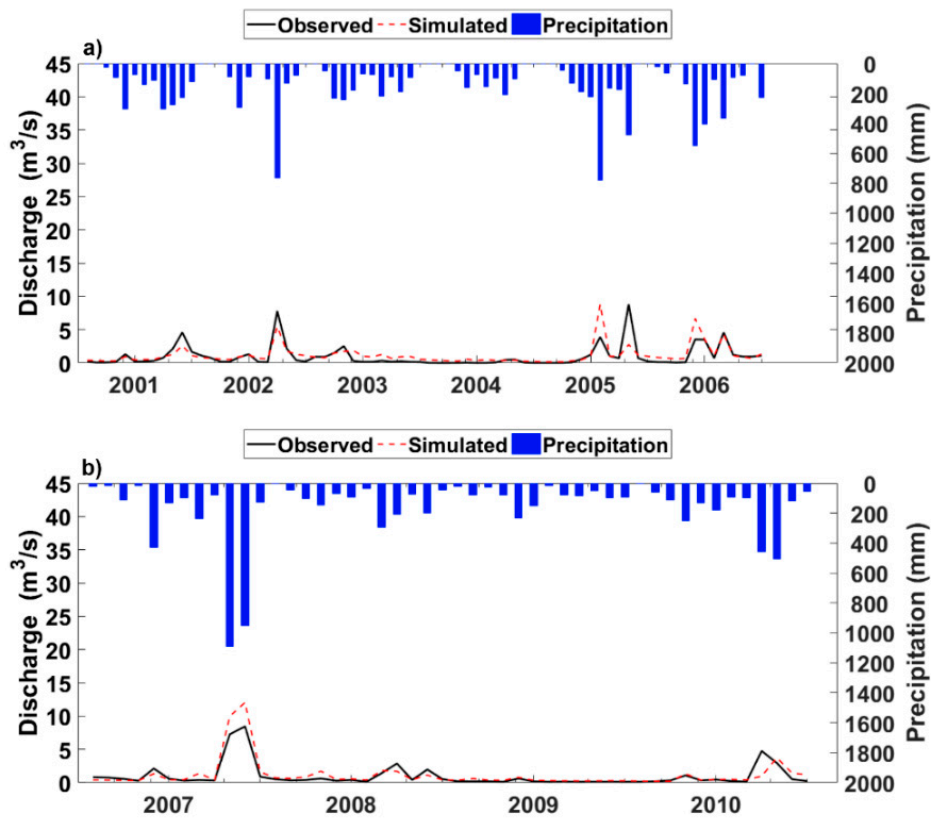

Figure 4. Monthly rainfall and observed and simulated mean monthly discharges during (a) calibration (2001-2006) and (b) validation (2007-2010) periods for Las Coloradas subbasin.

The model predictions in both subbasins ensured a proper simulation for the two periods, as shown in Table 4. However, better simulations of the mean annual streamflow were achieved in La Fuente subbasin characterized by higher streamflows than in Las Coloradas subbasin located at a higher altitude. The observed mean annual flow rate in La Fuente was $18.22 \mathrm{~m}^{3} / \mathrm{s}$, while SWAT simulated $17.50 \mathrm{~m}^{3} / \mathrm{s}$ in the calibration period. In the validation period, the observed flow rate was $25.24 \mathrm{~m}^{3} / \mathrm{s}$, and the simulated mean annual streamflow was $22.42 \mathrm{~m}^{3} / \mathrm{s}$. This similarity was the result of tuning the CN2, SOL_AWC, and SOL_K parameters during the calibration, which allowed for an improved simulation of infiltration and surface discharge for this subbasin.

Calibration in Las Coloradas was complicated as extreme precipitation events produced large overestimation of streamflows. We attempted to improve the model performance by changing the initial range of the threshold water depth in the shallow aquifer (GWQMN) and some surface parameters such as the soil available water capacity (SOL_AWC), the soil moist bulk density (SOL_BD), the soil saturated hydraulic conductivity (SOL_K), and the Manning's " $n$ " coefficient for overland flow (OV_N). Table 2 shows the initial ranges finally chosen following the recommendations of Abbaspour et al. [23], 
when large peaks of streamflow are overestimated. The results for Las Coloradas show a mean annual stream flow rate of $13.83 \mathrm{~m}^{3} / \mathrm{s}$, while the observed was $11.58 \mathrm{~m}^{3} / \mathrm{s}$. During the validation period, the observed mean streamflow rate was $11.56 \mathrm{~m}^{3} / \mathrm{s}$, while SWAT simulated $15.50 \mathrm{~m}^{3} / \mathrm{s}$. The annual discharges for both calibration and validation periods (Table 4 , Figure $5 \mathrm{~b}, \mathrm{~d}$ ) continue to overestimate the streamflow, especially in Las Coloradas, as seen also in Table 3.

Table 4. Evaluation measures of mean annual streamflow during the calibration (2001-2006) and validation (2007-2010) periods for average climatological values.

\begin{tabular}{cccccc}
\hline Subbasin & $\begin{array}{c}\text { Rainfall } \\
(\mathbf{m m} / \text { year })\end{array}$ & $\begin{array}{c}\text { Observed } \\
\text { Streamflow } \\
\left(\mathbf{m}^{\mathbf{3}} / \mathbf{s}\right)\end{array}$ & $\begin{array}{c}\text { Simulated } \\
\text { Streamflow } \\
\left(\mathbf{m}^{\mathbf{3}} / \mathbf{s}\right)\end{array}$ & $\begin{array}{c}\text { Mean } \\
\text { Difference } \\
\left(\mathbf{m}^{\mathbf{3}} / \mathbf{s}\right)\end{array}$ \\
\hline \multirow{2}{*}{ Calibration } & La Fuente & 1653 & 18.22 & 17.50 & -0.72 \\
& Las Coloradas & 1627 & 11.58 & 13.83 & 2.25 \\
\hline \multirow{2}{*}{ Validation } & La Fuente & 1935 & 25.24 & 22.42 & -2.82 \\
& Las Coloradas & 1927 & 11.56 & 15.50 & 3.94 \\
\hline
\end{tabular}

In addition to the temporal variations of the streamflow, the model provides estimates of the main water balance and flow components in the two subbasins; these results are shown in Table 5. In La Fuente subbasin, actual evapotranspiration (AET) represented $38 \%$ and $37 \%$ of the total precipitation (P) during the calibration and validations periods, respectively. Total runoff (TotalQ) accounted for by $40 \%$ and $39 \%$ of the water input via $P$ during the calibration and validation periods, respectively. The major component of the discharge was the lateral flow (LATQ), while the relevance of surface (SURQ), and groundwater (GWQ) flows were minor. The results were similar in Las Coloradas subbasin, where AET represented $47 \%$ and $49 \%$ of P during the calibration and validation periods, respectively, while the relative contribution of TotalQ to the water balance was equivalent to $35 \%$ and $33 \%$ of $P$ during the calibration and validation periods, respectively (Table 5). Again, LATQ was the main flow component, followed by SURQ. Considering SWAT functioning, aquifer and soil storage together may account for the percentage of $P$ unexplained by AET and TotalQ in the simulations [36].

Table 5. Mean annual water balance (WB) and flow components ( $\mathrm{mm}$ ) simulated by SWAT for La Fuente and Las Coloradas subbasins during the calibration (2001-2006) and validation (2007-2010) periods. P: precipitation, AET: actual evapotranspiration, SURQ: surface flow, LATQ: lateral flow, GWQ: groundwater, and TotalQ: total flow.

\begin{tabular}{ccccc}
\hline \multirow{2}{*}{ Component } & \multicolumn{2}{c}{ La Fuente } & \multicolumn{2}{c}{ Las Coloradas } \\
\cline { 2 - 5 } & Calibration & Validation & Calibration & Validation \\
\hline P & 1653 & 1935 & 1627 & 1927 \\
AET & 630 & 711 & 769 & 950 \\
SURQ & 94 & 178 & 243 & 250 \\
LATQ & 511 & 519 & 307 & 375 \\
GWQ & 57 & 50 & 13 & 17 \\
TotalQ & 662 & 747 & 563 & 642 \\
\hline
\end{tabular}

Regarding the flow components, the hydrological behavior observed in the two subbasins is typical of mountainous landscapes with steep slopes that favor direct runoff (i.e., SURQ and LATQ). This is also observed in other tropical basins [69] where similar results are reported. The higher contribution of GWQ in La Fuente than in Las Coloradas may be explained by its lower slopes, which might favor higher recharge. Because the water balance and flow components are in agreement with the expected values of such variables in the study area, the model can be further used for the evaluation of climate change scenarios.

\subsection{Analysis of Historical Simulations}

Figure 5 shows the interannual variation of annual precipitation and streamflow for La Fuente and Las Coloradas subbasins for the 1970-2010 baseline period; the mean annual precipitation in La Fuente 
is approximately $200 \mathrm{~mm}$ higher than in Las Coloradas (Table 1). This, together with the larger surface runoff production in La Fuente, favors a larger annual streamflow $\left(16.9 \mathrm{~m}^{3} / \mathrm{s}\right)$ than in Las Coloradas $\left(10.8 \mathrm{~m}^{3} / \mathrm{s}\right)$. During the baseline period, precipitation, and streamflow in the subbasins did not show a significant trend, but these were characterized by large interannual variability, which could be related to tropical cyclone activity and the contribution of ENSO to winter precipitation [6]. The boreal winter dry season precipitation (November-April) in the subbasins is statistically significant, correlated (0.46; $p<0.05)$ with the November-January Oceanic El Niño Index (ONI), so El Niño years tend to favor larger winter precipitation in the region. The correlation between precipitation and streamflow in Las Coloradas $(r=0.81)$ is larger than in La Fuente $(r=0.54)$, likely due to hydrological differences among the subbasins. While the simulated annual streamflow for both subbasins is similar to the observations, as reflected by the high correlation values in La Fuente $(r=0.89)$ and Las Coloradas $(r=0.92)$, a systematic positive bias is noted in the annual streamflow simulation in Las Coloradas.
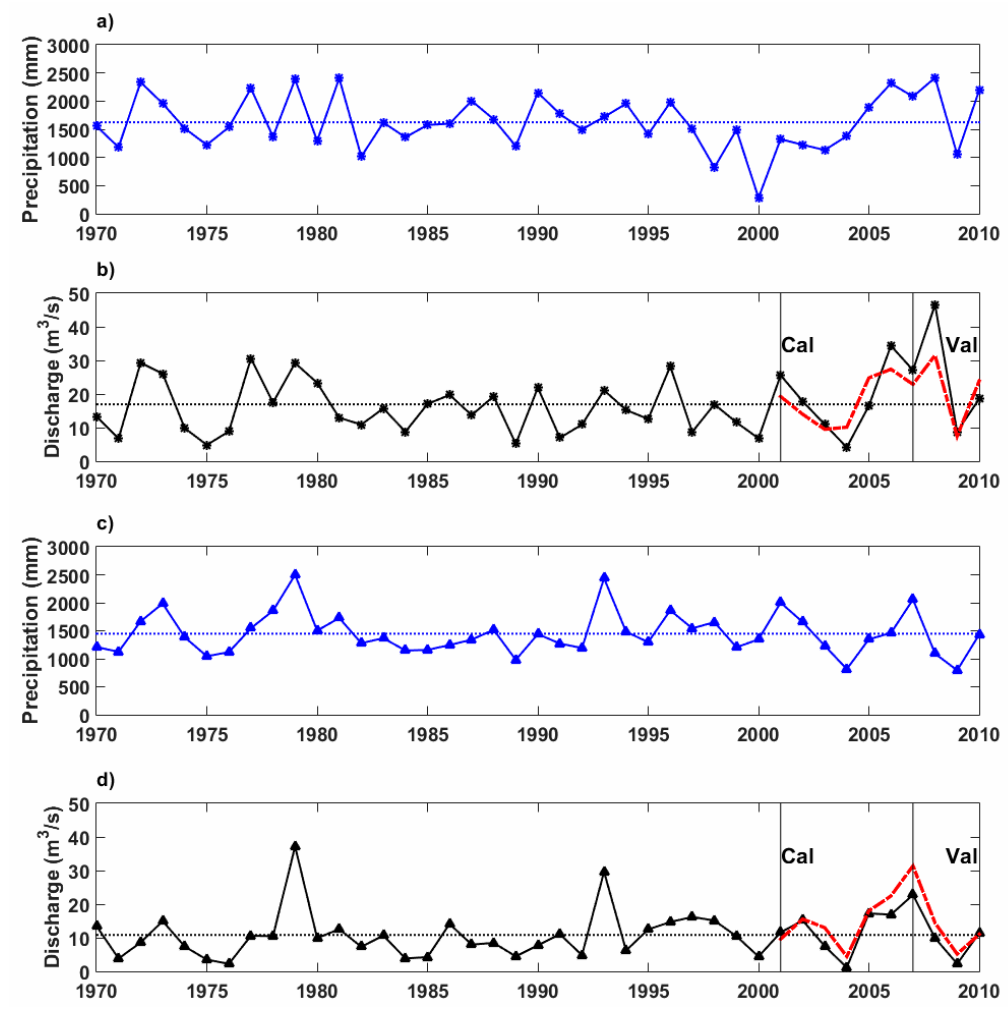

Figure 5. Interannual variation of precipitation and observed (solid black) and simulated (broken red) streamflow discharge in La Fuente (a,b) and in Las Coloradas (c,d) subbasins during 1970-2010. $\mathrm{Cal}$ and Val indicate calibration and validation periods, respectively, separated by vertical lines. Dotted horizontal lines represent mean values over the 1970-2010 period.

Annual cycles of precipitation and streamflow for the baseline (1970-2010) and the calibration and validation (2001-2010) periods are shown in Figure 6. Precipitation is characterized by a bimodal distribution with peaks in May and October during the rainy season and a mid-summer drought (MSD) in July. In the 2001-2010 period, there is a slight decrease in winter precipitation at the beginning of the year, but the annual cycle is more intense at the end of the summer in comparison with the baseline period (1970-2000).

The annual streamflow cycle for the 1970-2000 period shows the highest discharges in May and October, when the most important precipitations are received, and smaller flows in the dry season from November to April. During 2001-2010, there are significantly lower discharges in all months, which are well simulated by SWAT. Causes for the reduction of the discharge in the recent period may 
be partially explained by changes in land use [28]. Satellite images of the land uses for 1970-2000 and 2001-2010 show large areas of deforestation and land-use changes to agriculture in the most recent period. In the last months of the rainy season, a second peak of rainfall and of the streamflow occur after the MSD, but the discharge is still lower than during the first period (1970-2000). In general, the model captures well the streamflow seasonality, although in Las Coloradas the model shows a general tendency to overestimate during the summer months and in La Fuente to underestimate in some months of the year.
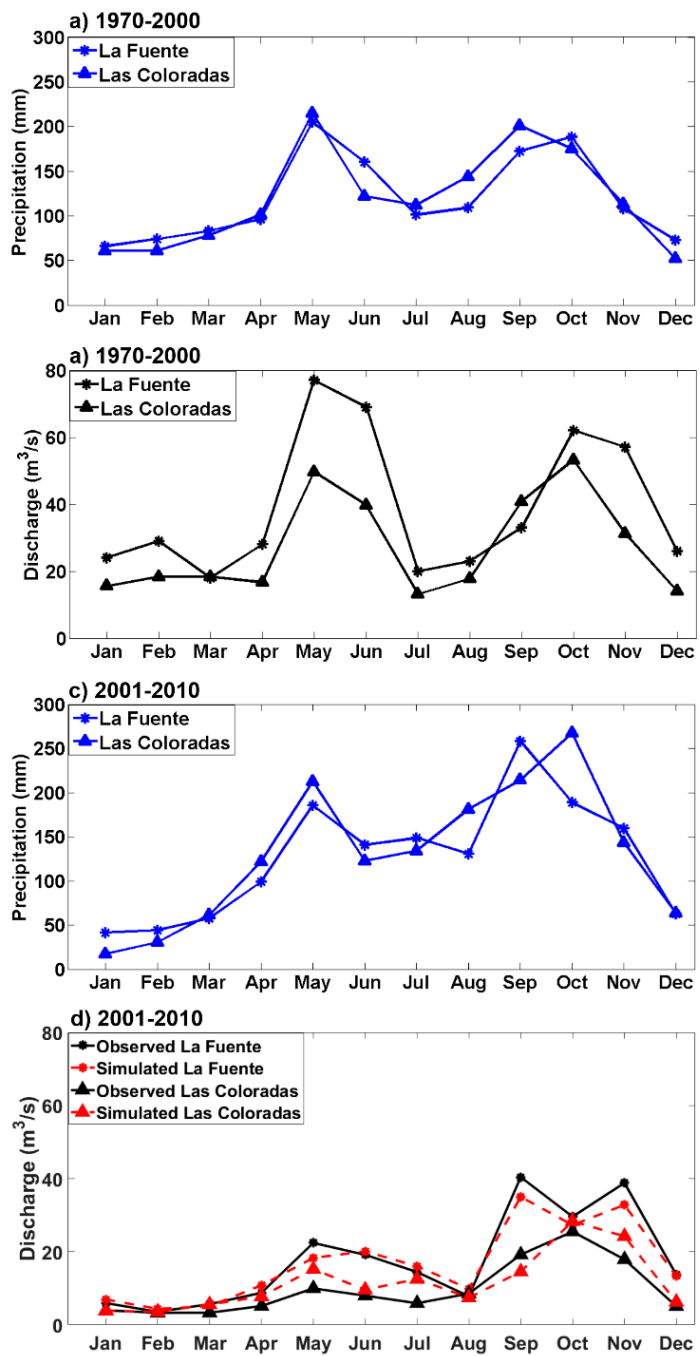

Figure 6. Annual cycles of precipitation and simulated streamflow discharge in La Fuente and Las Coloradas subbasins for the baseline (1970-2000) period (a,b) and the calibration and validation periods (c,d). Observed discharge in La Fuente and Las Coloradas are only available and shown for the period of 2001-2010.

\subsection{RegCM4.3 Evaluation}

Figure 7 shows the annual cycles of precipitation and temperatures using observed data and model outputs for grid points over the Cauto River basin to evaluate the representativeness of the RegCM4.3 climate model. The comparison shows a good agreement between the two observed databases (CRU and station data), highlighting the bimodality of precipitation. However, CRU has the peaks of rainfall in May and September, while the station peaks occur in May and October (similar to RegCM4.3 and HadGEM2-ES), owing the second peak to the influence of tropical cyclones. The discrepancy in the occurrence of the second maximum could be related to the grid resolution $(50 \mathrm{~km})$ of CRU. In using 
CRU data, Karmalkar et al. [4] stated that the annual cycle of precipitation in the western Caribbean is predominantly bimodal with the first maximum in May or June and the second maximum between August and November, depending on the location.

Both the regional and global models simulated adequately the annual cycle of precipitation and showed the observed bimodality according to the stations, but RegCM4.3 slightly underestimated the observed annual precipitation in la Fuente (by 16\%) and Las Coloradas (by 15\%).

Despite this underestimation, RegCM4.3 improved the monthly precipitation with respect to the HadGEM2-ES global model used as forcing (Figure 7a). The underestimation of RegCM4.3 could be related to the choice of convective parameterizations used [15,55]. Furthermore, the general pattern of the annual cycles of mean, maximum, and minimum temperatures were captured by RegCM4.3 and HadGEM2-ES, as compared with CRU and the climate stations (Figure 7b-d). However, the two models tended to underestimate the maximum temperature and overestimate the minimum temperature. The highest maximum temperatures occur during the summer, and both models point to July and August as the hottest months, consistent with observations, but RegCM4.3 significantly underestimated the maximum temperature by $4{ }^{\circ} \mathrm{C}$ during the summer, which may have an impact on the water balance.
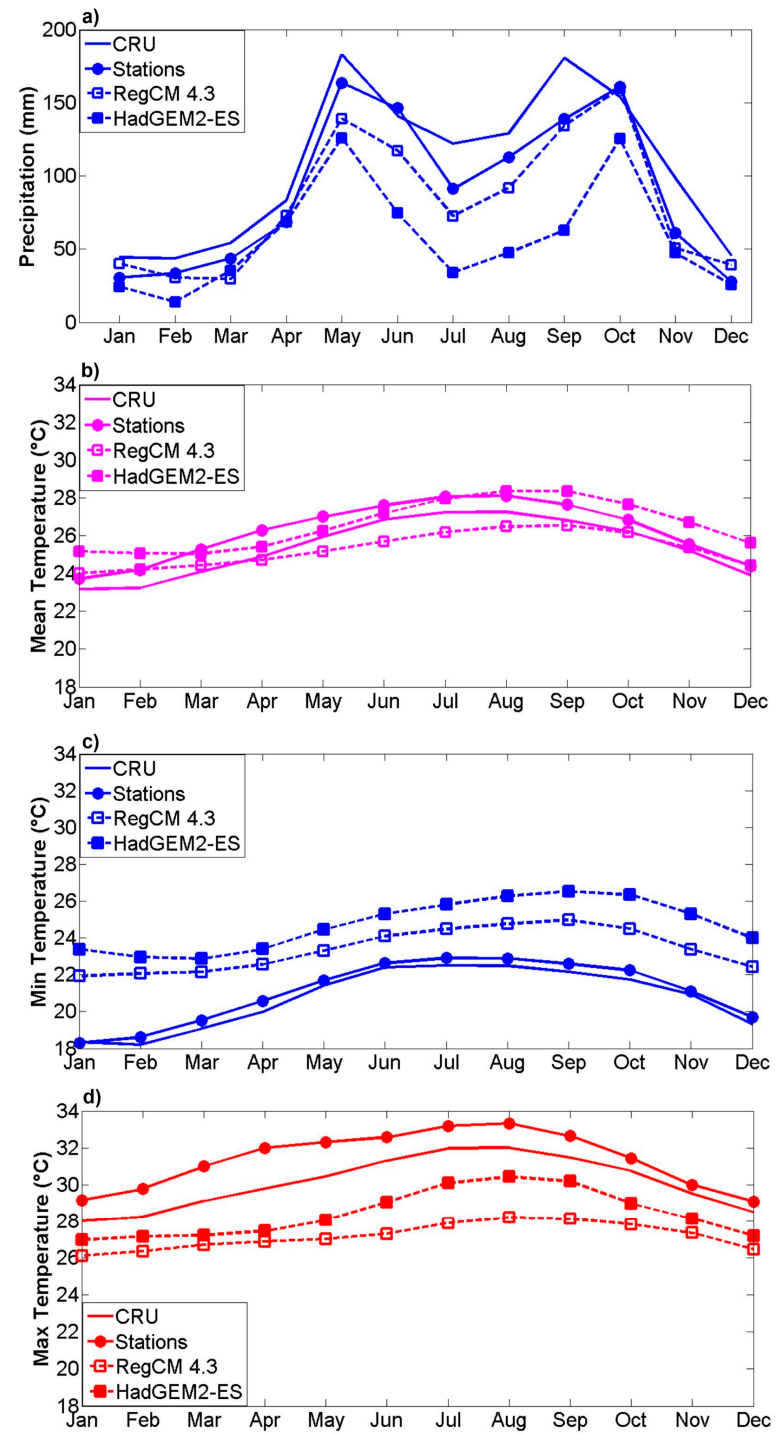

Figure 7. Mean annual cycles of (a) precipitation, (b) mean temperature, (c) minimum temperature, and (d) maximum temperature in the Cauto River basin according to observations (climate stations and CRU) and models (RegCM4.3 and HadGEM2-ES) for the period 1970-2000. 


\subsection{Impact of Climate Change on Hydrology}

Figure 8 shows the future changes (2015-2039 relative to 1970-2000) of precipitation and temperature in the Cauto River basin and in the subbasins derived from RegCM4.3 under the most extreme climate scenario (RCP 8.5). The projections suggest a drier rainy season from May to October and a slight increase of precipitation in March, at the end of boreal winter. The future scenarios for temperature are all positive, but the increase is greater in summer than in winter $\left(>1.4^{\circ} \mathrm{C}\right)$, which could have significant effects on the total streamflow. The mean climate during 2015-2039 is projected to be drier $(-18 \%)$ and warmer $\left(+1.5^{\circ} \mathrm{C}\right)$ relative to $1970-2000$ (Table 6$)$. These results are consistent with prior studies that show a significant reduction of summer rainfall in the Caribbean region [70-72] and in the Cauto River basin [73]. The projected changes in winter precipitation are small and positive, which could be related to possible increases in the frequency and intensity of the ENSO-related events [5,6]. Table 6 also shows the projected changes of temperature and precipitation for 2070-2096 relative to 1970-2000 under the RCP 8.5 scenario in the Cauto river basin. These results suggest a significant increase of temperature $\left(+3.3^{\circ} \mathrm{C}\right)$ and a possible reduction in annual precipitation of $-25 \%$. The 21st century trends of temperature and precipitation in the region suggest potential negative impacts in the streamflow, as described below for the near future.

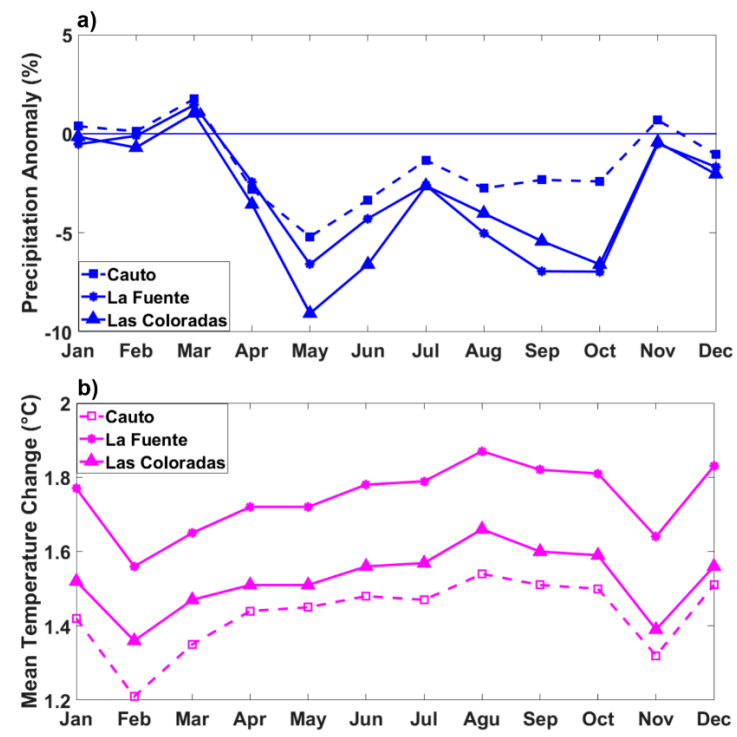

Figure 8. Future changes in mean monthly (a) precipitation and (b) temperature for the Cauto River basin and La Fuente and Las Coloradas subbasins according to the regional model RegCM4.3 under the Representative Concentration Pathway (RCP) 8.5 scenario for 2015-2039 with respect to 1970-2000. Monthly changes of precipitation are relative to their annual contribution.

Table 6. RegCM4.3 mean changes of annual temperature and precipitation under the RCP 8.5 scenario for 2015-2039 and 2070-2096 relative to 1970-2000 for the Cauto River basin and La Fuente and Las Coloradas subbasins.

\begin{tabular}{ccc}
\hline Basin and Subbasins & Mean Temperature Change $\left({ }^{\circ} \mathbf{C}\right)$ & $\begin{array}{c}\text { Mean Annual Precipitation Change (\%) } \\
\text { 2015-2039 }\end{array}$ \\
\hline Cauto & 1.4 & -18 \\
La Fuente & 1.8 & -36 \\
Las Coloradas & 1.5 & -41 \\
\hline & & \\
\hline Cauto & 3.3 & -25 \\
La Fuente & 4.0 & -44 \\
Las Coloradas & 3.9 & -47 \\
\hline
\end{tabular}


Table 7 shows the historical and future scenarios of the water balance components in the two subbasins. The annual precipitation may decrease between $36 \%$ and $41 \%$, but RegCM4.3 showed $15 \%$ underestimation during the historical period with respect to the station data (Figure 7a), and bias correction was not applied to precipitation before running SWAT. Under these considerations, future scenarios from SWAT for 2015-2039 suggest that the total flow (TotalQ) in La Fuente and Las Coloradas subbasins could be reduced by $-53 \%$ and $-61 \%$, respectively (Table 7 ). These results are consistent with other studies from the Caribbean region that project a reduction of streamflow during the wet season [74]. These findings are also in line with Arnell [75], who reported a similar behavior in other Caribbean islands.

Potential evapotranspiration (PET) increases slightly in the RCP 8.5 scenario associated with the mean temperature increase. Despite this increase in PET, AET decreases in La Fuente $(-25 \%)$ and in Las Coloradas $(-31 \%)$. Such a reduction is associated with lower soil water availability for evapotranspiration due to a reduction in precipitation (especially during summer, Figure 9). However, the percentage of precipitation lost through AET is expected to increase in the future scenario (Table 7). From this analysis, it is clear that decreases in the hydrological components are associated with the projected changes in precipitation (reduction) and temperature (increase). Other studies have also pointed out that hydrological components are especially sensitive to a decrease in precipitation and high temperatures [76,77].

Total aquifer recharge could also decrease up to $-52 \%$ in La Fuente and $-63 \%$ in Las Coloradas in 2015-2039 compared with the baseline period. Accordingly, groundwater flow contribution to streamflow is expected to decrease (71\% in the La Fuente and $64 \%$ in Las Coloradas, Table 7). The reduction of precipitation and the higher percentage of water loss via AET may explain this process.

Table 7. Baseline and future RCP 8.5 scenarios of mean annual water balance components (mm) and their annual percentage (\%) changes in La Fuente and Las Coloradas subbasins. The percentage change is for 2015-2039 relative to 1970-2000. P: precipitation, PET: potential evapotranspiration, AET: actual evapotranspiration, TotalQ: total flow, SURQ: surface flow, LATQ: lateral flow, GWQ: groundwater flow, and AQR: total aquifer recharge.

\begin{tabular}{cccc}
\hline Component & RegCM4.3 (Baseline) (1970-2000) $(\mathbf{m m})$ & RegCM4.3 (RCP 8.5) (2015-2039) (mm) & Change (\%) \\
\hline La Fuente & & & -36 \\
\hline P & 1191 & 765 & 2 \\
PET & 1260 & 1289 & -25 \\
AET & 725 & 541 & -53 \\
Total & 273 & 128 & -58 \\
SURQ & 45 & 19 & -51 \\
LATQ & 212 & 104 & -71 \\
GWQ & 17 & 5 & -52 \\
AQR & 209 & 100 & -41 \\
\hline Las Coloradas & & & 3 \\
\hline P & 1182 & 694 & -31 \\
PET & 1262 & 1300 & -61 \\
AET & 800 & 550 & -62 \\
TotalQ & 261 & 101 & -60 \\
SURQ & 98 & 38 & -64 \\
LATQ & 156 & 62 & -63 \\
GWQ & 5 & 2 & 42 \\
AQR & 116 & & \\
\hline
\end{tabular}

In the annual cycle, the projections of the water balance components show different seasonal responses (Figure 9). The largest positive and negative changes are observed in the TotalQ component in the subbasins. This indicates the high sensitivity of surface runoff to changes in precipitation input, especially during the summer. An interesting observation from Figure 9 is that evapotranspiration is less sensitive to precipitation, with a moderated set of changes in its behavior throughout the year. AET is especially reduced from spring to early autumn when $P$ is expected to decrease. The reduction of $\mathrm{P}$ is more noticeable in the summer, consistent with the precipitation projections for the Caribbean $[70,71]$. 
This reduction and the increase of temperature could affect the aquifer recharge in the subbasins during the summer in the near future. In winter, the precipitation change is small, with a minor increase (decrease) in March (December). These changes would affect negatively the TotalQ, especially in May and October, as seen in Figure 9.
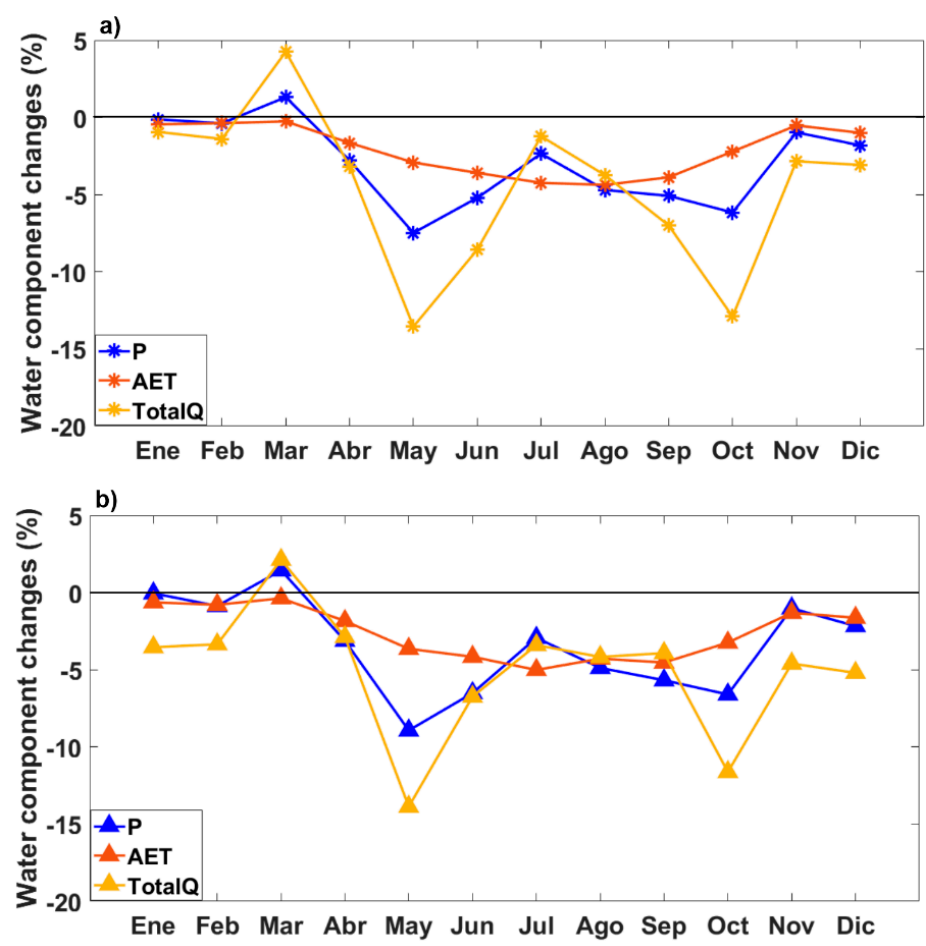

Figure 9. Future changes in water balance components for (a) La Fuente and (b) Las Coloradas subbasins under the RCP 8.5 scenario for the 2015-2039 period with respect to the baseline period (1970-2000). P is precipitation, AET is actual evapotranspiration, and TotalQ is total flow. The monthly changes are relative to their annual contribution.

\subsection{Total Water Storage}

Total water storage (TWS) obtained from the monthly water balance as TWS $=\mathrm{P}-($ TotalQ + AET $)$ is shown in Figure 10 for the baseline period and the future scenario. The TWS equation is simple and has been used for various purposes [78,79]. In a recent paper, Thapa et al. [80] demonstrated that basin-scale estimates of TWS with SWAT are successful. Their study focused on the use of three hydrological models (SWAT, HBV, and BTOPMC) to analyze the water balance components and their temporal and seasonal variations. SWAT was better than the other models, and it captured well the flow patterns in most of the seasons. For the Cauto River basin, TWS shows positive values during the rainy season (May-October) and negative ones during the dry season (Figure 10). Negative storage is also observed in July during the MSD season. A generally good agreement was found between TWS and rainfall in the two subbasins. During the baseline period, TWS varied from $+45 \mathrm{~mm}$ to $-7 \mathrm{~mm}$ in the La Fuente subbasin, while in Las Coloradas, TWS varied from $+57 \mathrm{~mm}$ to $-26 \mathrm{~mm}$. This implies that La Fuente subbasin is able to store slightly more water in the rainy season, which is then used during the dry season, whereas the faster runoff response in Las Coloradas impedes a larger storage in the rainy season and releases less during the dry periods.

In the near future, the annual cycle of TWS is similar to the baseline period, but it is lower during the summer (Figure 10a,b); a positive value in early winter (January, February, and March) is seen in both subbasins. This behavior in storage could be related to the projected significant decrease of precipitation during the summer and a slight increase of precipitation during boreal winter (Figure 8). On average, annual TWS could fluctuate in the future from $+30 \mathrm{~mm}$ to $-2 \mathrm{~mm}$ in La Fuente and from 
$+35 \mathrm{~mm}$ to $-12 \mathrm{~mm}$ in Las Coloradas subbasin. TWS data provides an important source of information for the hydrological cycle simulation in the subbasins and may give a rough estimate of the hydrologic variables for the future. However, these scenarios should be taken with caution, because they are based on a single RCM; moreover, RegCM4.3 has its own uncertainties based on the historical biases in the basin described in Section 3.3. Thus, these scenarios represent a possible future, and the methodology serves as a guidance for future hydro-climatic studies in the region.
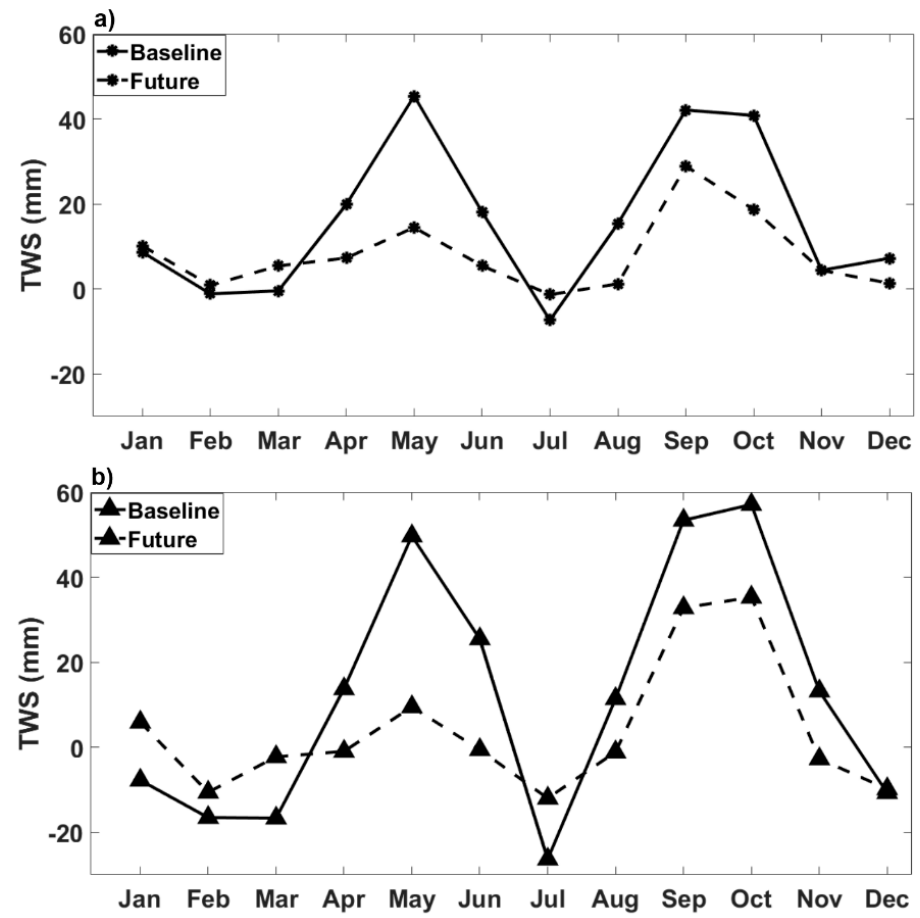

Figure 10. Monthly total water storage (TWS) for (a) La Fuente and (b) Las Coloradas subbasins for the baseline period (1970-2000) and the future (2015-2039) projection (broken lines) under the RCP 8.5 scenario.

\section{Discussion}

Based on the analysis produced by SWAT, the simulated streamflows are generally consistent with observations from the two (middle- and high-altitude) subbasins in the Cauto River during the calibration period. The peak monthly flows were captured well in most cases, although tended to be overestimated in some events; but, discharge was not estimated with precision during low flow periods and during the largest flows, especially in the high-altitude subbasin (Las Coloradas). Low SWAT performances during dry conditions have been also documented by other authors $[64,65]$. The relatively low skill of the model in Las Coloradas is partially associated with the objective functions or performance indexes used to calibrate the model, which tend to rely more on flood features [63], especially NSE. However, this metric was used because peak events are a very important feature in tropical regions and because NSE is the most used performance statistic in the SWAT literature. There are also physical factors that may explain the low performance of SWAT in a tropical region. First of all, the limited length of the observational dataset, which did not include all types of extreme events during both the calibration and validation periods, was consistent with Stehr et al. [81]. Secondly, parameter values might change (from the calibration to the validation period) due to different vegetation or climate conditions [82]. A final factor is that the baseline recession parameters possibly did not vary enough during calibration; a similar behavior was found in a tropical basin in Brazil [83].

Despite the modest performance in the Las Coloradas subbasin during the validation period, the overall performance over the calibration period ranged from "good" to "satisfactory" in the two 
subbasins; this justifies the use of the calibrated SWAT model for subsequent simulation of the potential impacts of climate change on water availability. This is very relevant, because this work comes from a region of the world that has been typically understudied by SWAT modeling works.

The RegCM4.3 historical simulations showed an underestimation of summer precipitation in the basin, as compared with the station data, but improved the precipitation compared to its forcing global model (HadGEM2-ES). It is likely that the underestimation of RegCM4.3 is related to the poor representation of some components of the hydrological cycle (i.e., soil moisture, surface fluxes and vegetation types, or the convective parameterization) as explained by Martínez-Castro et al. [14,15]. Other regional climate models, such as PRECIS, also tend to underestimate precipitation in the Caribbean islands $[16,70]$. The complex interaction between the small islands and the ocean may also be a limiting factor.

In this study, we found that the impact of climate change would be to decrease precipitation and water components during the wet season from May to October and to slightly increase precipitation during boreal winter. These results are consistent with projections documented by other models for the Caribbean [4,57]. The precipitation response projected under the RCP 8.5 emission scenario suggests that dry conditions could be intensified during the summer in the Cauto River basin in the near future. The future scenarios for temperature were all positive, but the increase was greater during the summer $\left(>1.4^{\circ} \mathrm{C}\right)$ than in winter, which could have negative effects on the total streamflow. The hydrological response to the combined impacts of temperature and precipitation changes would lead to water shortages (as suggested by the SWAT simulation) and the need for a better and more efficient planning of short-term water delivery in the subbasins. The findings presented here, based on SWAT simulations, suggest a significant reduction in surface and groundwater availability in the two subbasins in the near future (2015-2039, relative to the baseline period), with the largest decreases expected during the boreal summer rainy season. The differences in future hydrologic projections in comparison to historical conditions are notable.

Furthermore, estimated values of TWS reveal decreases in water storage during the summer and a small, but positive, storage change in boreal winter, which suggest that seasonal fluctuations of water balance components need to be accounted for. Nevertheless, these results may be taken with caution considering the aforementioned weaknesses of SWAT modeling during dry conditions and during large peak flows, which may not be fully capturing the dynamics of the groundwater component of the hydrologic system [21].

We recognize that this study has some limitations, which in future studies can be reduced by considering some of the following issues. (1) The climate change impact is addressed here using only one hydrological model (SWAT) and two forcing variables (precipitation and temperature), neglecting other near-surface atmospheric factors, which might affect runoff generation. (2) The SWAT parameters used during the calibration period were kept the same for the historical and future scenario simulations. This assumption could carry uncertainties into scenario simulations depending on the extent of future technological and climate changes. (3) The use of a SWAT generic agricultural land use with default management operations might be another weakness of the model. Not specifying crop types and the management practices in the study region might lead to errors, particularly regarding evapotranspiration. Recent results (i.e., Pierini et al. [84]; Qiao et al. [85]) have shown that detailed biophysical parameters of crop species can improve the performance of distributed, physically-based models, such as SWAT, and reduce model uncertainty. Nevertheless, land use in our two calibrated subbasins is dominated by forest and pasture, while agriculture is minor. (4) RegCM4.3 downscaling of the HadGEM2-ES model underestimated precipitation by 15\% during the historical period as compared with the station data. (5) RegCM4.3 simulations were applied to SWAT without a bias correction, which has advantages [10,86] and disadvantages [87]. (6) SWAT was forced with a single RCM (RegCM4.3 forced with HadGEM2-ES) and a single emission scenario (RCP 8.5). However, in our particular case, before the year 2050, all RCP projection scenarios are very similar [32], which in this case justifies the use of a single emission scenario. Moreover, the climate results presented here are 
consistent with other studies for the Caribbean region based on different RCMs (Martínez-Castro et al. [15]; Taylor et al. [70]) and GCMs [57]. Even though we did not assess the changes in the hydrology in the far future, climate projections for 2070-2096 suggest more drastic changes in temperature and precipitation (i.e., Campbell et al. [3]; Karmalkar et al. [4]), consistent with the signs of the changes in our study.

\section{Conclusions}

The objective of this study was to assess for the first time in Cuba the impacts of the projected climate change on water resources in two subbasins of the Cauto River using the soil and water assessment tool (SWAT) model. The regional climate model RegCM4.3 was used to force the calibrated SWAT models to simulate a baseline (1970-2000) period and near-future (2015-2039) hydrologic regimes under the RCP 8.5 emission scenario.

The main findings from this modeling study can be summarized as follows:

(1) Based on the future projections, temperatures across the Cauto river basin suggest regional increases of $1.5{ }^{\circ} \mathrm{C}$ in the mean annual temperature and an $18 \%$ decrease in the mean annual precipitation, with the largest decreases expected during the boreal summer rainy season.

(2) Under these conditions, the surface water resources in the Cauto River basin may experience considerable changes. Based on the RCP 8.5 projections, the average reduction in discharge could be close to $-53 \%$ in the mid-altitude (La Fuente) and $-61 \%$ in the high-altitude (Las Coloradas) subbasins. The SWAT model also suggested a reduction of the aquifer recharge of $-52 \%$ in La Fuente and $-63 \%$ in Las Coloradas, with effects on the contribution of groundwater flow. These changes might be driven by a decrease in precipitation in most months, but especially during the summer, and a high percentage of water loss through AET.

(3) The hydroclimatic projections shown here represent possible scenarios for the Cauto basin in the near future; our results provide guidelines for decision makers on how climate change may affect water availability in the Cauto River basin, as it has been done for other watersheds in the world. Moreover, the knowledge of a possible increase of approximately $1.5^{\circ} \mathrm{C}$ and a possible reduction of summer streamflow in the basin during 2015-2039 (relative the base period) is strategic for Cuba in the context of its intended nationally determined contributions (INDCs) under the Paris Agreement, especially for the country's adaptation actions.

(4) Finally, prior to this investigation no similar modeling approach (SWAT with RegCM4.3) was available in the country; the tools used here can be transferred to water resources managers in the Cauto River basin and the methodology can be improved by scientists in the region to reduce future uncertainties using different SWAT parameters and other regional models and emission scenarios.

Author Contributions: Y.M.-Z., T.C., and T.K. designed the framework of the study. Y.M.-Z. performed the data preparation, SWAT modeling, and analysis of RegCM4 climatologies. E.M.-N. contributed to the calculations in SWAT-CUP and advised during the SWAT modeling process. T.C., E.R.V., G.C., and T.K. contributed their knowledge on conceptual and scientific issues. Y.M.-Z. and T.C. prepared the first versions of the manuscript. All authors contributed to the interpretation of the results and reviews of the manuscript.

Funding: This study was funded by the Center for Scientific Research and Higher Education at Ensenada (CICESE, Project 644130) and the Consejo Nacional de Ciencia y Tecnología de México (CONACyT, Grant 381779). Eugenio Molina Navarro has been supported by the Ramón Areces Foundation postgraduate studies programme, the BONUS Go4Baltic project, and the EU Joint Programming Initiative (JPI) Climate WATExR project.

Acknowledgments: The authors would like to thank the Consejo Nacional de Ciencia y Tecnología (CONACyT, México) for a PhD scholarship to the first author.The Instituto Nacional de Meteorología de Cuba (INSMET), Instituto de Investigaciones Agropecuarias "Jorge Dimitrov", Ministerio de Ciencia Tecnología y Medio Ambiente de Cuba, and Empresa de Aprovechamiento Hidráulico (GEARH) are gratefully acknowledged for providing data. The authors appreciate the contributions of the following individuals from GEARH in obtaining hydro-climatic station data for the Cauto River basin: Francis Francisco Rodríguez, Angel Sánchez, Alfredo Remón, Hipolito Torres, Guadalupe Bermudez, Celia Yaima Garces Batista, and Fermín Sarduy. Enrique R. Vivoni and T. Cavazos 
would like to thank the U.S. Fulbright-Garcia Robles and CONACYT fellowships for the support during Vivoni's sabbatical period at CICESE (2015-2016).T. Cavazos is thankful for the support of the Associate Program of the International Centre for Theoretical Physics (ICTP) during her scientific visit in 2018.

Conflicts of Interest: The authors declare no conflicts of interest.

\section{References}

1. Ficklin, D.L.; Stewart, I.T.; Maurer, E.P. Climate Change Impacts on Streamflow and Subbasin-Scale Hydrology in the Upper Colorado River Basin. PLoS ONE 2013, 8, 8-19. [CrossRef] [PubMed]

2. Parry, M.L.; Canziani, O.F.; Palutikof, J.P.; van der Linden, P.J.; Hanson, C.E. (Eds.) Climate Change 2007: Impacts, Adaptation and Vulnerability. In Contribution of Working Group II to the Fourth Assessment Report of the Intergovernmental Panel on Climate Change; Cambridge University Press: Cambridge, UK; New York, NY, USA, 2007.

3. Campbell, J.D.; Taylor, M.A.; Stephenson, T.S.; Watson, R.A.; Whyte, F.S. Future climate of the Caribbean from a regional climate model. Int. J. Climatol. 2010, 31, 1866-1878. [CrossRef]

4. Karmalkar, A.V.; Taylor, M.A.; Campbell, J.; New, M.; Centella, A.; Benzanilla, A. A review of observed and projected changes in climate for the islands in the Caribbean. Atmosphere 2013, 26, 283-309. [CrossRef]

5. Planos, E.O.; Rivero, R.; Guevara, V. Informe sobre Impacto del Cambio Climático y Medidas de Adaptación en Cuba; Segunda Comunicación Nacional de Cuba al Convenio Marco de las Naciones Unidas: Cuba, Caribbean, 2012. Available online: http:/ / research3.fit.edu/sealevelriselibrary/documents/doc_mgr/473/28.\%20Planos\% 20et\%20al.\%20\%20(2012).\%20\%20Impacts\%20and\%20Adaptation\%20to\%20CC\%20in\%20Cuba.pdf (accessed on 15 November 2017).

6. Planos, E.; Guevara, A.V.; Rivero, R. Cambio Climático en Cuba: Vulnerabilidad, Impacto y Medidas de Adaptación; Multimedia Instituto de Meteorología de Cuba: Lisbon, Portugal, 2013; ISBN 978-959-300-035-2.

7. Pulwarty, R.S.; Nurse, L.A.; Trotz, U.O. Caribbean islands in a changing climate. Environ. Sci. Policy Sustain. 2010, 52, 16-27. [CrossRef]

8. Safeeq, M.; Fares, A. Hydrologic response of a Hawaiian watershed to future climate change scenarios. Hydrol. Process. 2012, 26, 2745-2764. [CrossRef]

9. Ficklin, D.L.; Luo, Y.; Luedeling, E.; Zhang, M. Climate change sensitivity assessment of a highly agricultural watershed using SWAT. J. Hydrol. 2009, 374, 16-29. [CrossRef]

10. Hawkins, G.A.; Vivoni, E.R.; Robles-Morua, A.; Mascaro, G.; Rivera, E.; Domínguez, F.A. Climate Change Projection for Summer Hydrologic Conditions in a Semiarid Watershed of Central Arizona. J. Arid Environ. 2015, 118, 9-20. [CrossRef]

11. Mango, L.M.; Melesse, A.M.; Mclain, M.E.; Gan, D.; Setegn, S.G. Land use and climate change impacts on the hydrology of the upper Mara River Basin, Kenya: Results of a modeling study to support better resource management. Hydrol. Earth Syst. Sci. 2011, 15, 2245-2258. [CrossRef]

12. Jha, M.; Gassman, P.W. Changes in hydrology and streamflow as predicted by modeling experiment forced with climate models. Hydrol. Process. 2013, 28, 2772-2781. [CrossRef]

13. Jha, M.; Pan, Z.; Takle, S.E.; Gu, R. The Impacts of Climate Change on Stream Flow in the Upper Mississippi River Basin: A Regional Climate Model Perspective. J. Geophys. Res. Atmos. 2004, 109, 1984-2012. [CrossRef]

14. Martínez-Castro, D.; Da Rocha, R.P.; Benzanilla-Morlot, A.; Alvarez-Escudero, L.; Reyes-Fernández, J.P.; Silva-Vidal, Y.; Arritt, R.W. Sensitivity studies of the RegCM3 simulation of summer precipitation, temperature and local wind field in the Caribbean region. Theor. Appl. Climatol. 2006, 86, 5-22. [CrossRef]

15. Martínez-Castro, D.; Vichot-Llano, A.; Bezanilla-Morlot, A.; Centella-Artola, A.; Campbell, J.; Giorgi, F.; Viloria-Holguin, C. The performance of RegCM4 over the Central America and Caribbean region using different cumulus parameterizations. Clim. Dyn. 2017, 16, 77-98. [CrossRef]

16. Centella, A.; Taylor, M.A.; Bezanilla, A.; Martinez, D.; Campbell, J.D.; Stephenson, T.S.; Vichot, A. Assessing the effect of domain size over the Caribbean region using the PRECIS regional climate model. Clim. Dyn. 2015, 44, 1901-1918. [CrossRef]

17. Faramarzi, M.; Abbaspour, K.C.; Vaghefi, S.A.; Farzaneh, M.; Zehnder, A.J.B.; Srinivasan, R.; Yang, H. Modeling impacts of climate change on freshwater availability in Africa. J. Hydrol. 2013, 480, 85-101. [CrossRef] 
18. Trang, N.T.T.; Shrestha, S.; Shrestha, M.; Datta, A.; Kawasaki, A. Evaluating the impacts of climate and land-use change on the hydrology and nutrient yield in a transboundary river basin: A case study in the $3 S$ river basin (Sekong, Sesan, and Srepok). Sci. Total Environ. 2017, 576, 586-598. [CrossRef] [PubMed]

19. Anand, J.; Gosain, A.K.; Khosa, R.; Srinivasanb, R. Regional scale hydrologic modeling for prediction of water balance, analysis of trends in streamflow and variations in streamflow: The case study of the Ganga River basin. J. Hydrol. 2018, 16, 32-53. [CrossRef]

20. Shrestha, N.K.; Du, X.; Wang, J. Assessing climate change impacts on fresh water resources of the Athabasca River Basin, Canada. Sci. Total Environ. 2017, 60-61, 425-440. [CrossRef] [PubMed]

21. Molina-Navarro, E.; Hallack-Alegria, M.; Martínez-Pérez, S.; Ramírez-Hernández, J.; Mungaray-Moctezuma, A.; Sastre-Merlín, A. Hydrological modeling and climate change impacts in an agricultural semiarid region. Case study: Guadalupe River basin, México. Agric. Water Manag. 2016, 175, 29-42. [CrossRef]

22. Leta, O.T.; El-Kadi, A.I.; Dulai, H.; Ghazal, K.A. Assessment of climate change impacts on water balancecomponents of Heeia watershed in Hawaii. J. Hydrol. 2016, 8, 182-197.

23. Abbaspour, K.C.; Rouholahnejad, E.; Vaghefi, S.; Srinivasan, R.; Yang, H.; Kløve, B. A continental-scale hydrology and water quality model for Europe: Calibration and uncertainty of a high-resolution large-scale SWAT model. J. Hydrol. 2015, 524, 733-752. [CrossRef]

24. Sánchez, M.; Muñoz, A.; Sánchez, J.M.; Savine, S.; Viera, M.; Castellanos, L.; Vigo, Y.; Estupiñan, L.; Barcia, S. Determination of the Erosive Potential to Cienfuegos Bay in Cuba, Using the SWAT Hydrological Model. In Proceedings of the Conference International SWAT, Toulouse, France, 17-19 July 2013.

25. Mesa-Pérez, M.A.; Sánchez-Pérez, J.M.; Sauvage, S.; Váldes, R. Modeling pollutants inputs in a reservoir using SWAT model in the Mayabeque catchment (Cuba). In Proceedings of the Conference International SWAT, Toulouse, France, 17-19 July 2013.

26. Rodríguez, Y.; Marrero, N. Metodología para la simulación hidrológica de eventos extremos máximos en ausencia de datos hidrométricos a escala horaria. Revista Ciencias Técnicas Agropecuarias 2010, 19, $22-26$.

27. Rodríguez, Y. Modelación hidrológica de avenidas. Caso de estudio: Cuenca del río Zaza. In Tesis en Opción al Grado Científico de Doctor en Ciencias Técnicas. Centro de Investigaciones Hidráulicas; Instituto Superior Politécnico José Antonio Echeverría: La Habana, Cuba, 2011.

28. IPF (Instituto de Planificación Física). Diagnóstico Cuenca del Río Cauto, Granma, Cuba; Investigación Instituto de Planificación Física: Granma, Cuba, 2012.

29. Shrestha, B.; Babel, M.S.; Maskey, S.; van Griensven, A.; Uhlenbrook, S.; Green, A.; Akkharath, I. Impact of climate change on sediment yield in the Mekong River basin: A case study of the Nam Ou basin, Lao PDR. Hydrol. Earth Syst. Sci. 2013, 17, 1-20. [CrossRef]

30. Perra, E.; Piras, M.; Deidda, R.; Paniconi, C.; Mascaro, G.; Vivoni, E.R.; Pierluigi, C.; Marras, P.A.; Ludwig, R.; Meyer, R. Multimodel assessment of climate change-induced hydrologic impacts for a Mediterranean catchment. Hydrol. Earth Syst. Sci. 2018, 22, 4125-4143. [CrossRef]

31. UNFCCC. INDCs as Communicated by Parties. Available online: http://www4.unfccc.int/Submissions / INDC/Submission\%20Pages/submissions.aspx (accessed on 28 May 2018).

32. Cubasch, U.; Wuebbles, D. Projections of future climate change. In Climate Change 2001: The Scientific Basis, Contribution of Working Group I to the Third Assessment Report of the Intergovernmental Panel on Climate Change; Cambridge University Press: Cambridge, UK; New York, NY, USA, 2001; pp. 527-582.

33. Giorgi, F.; Coppola, E.; Solmon, F.; Mariotti, L. RegCM4: Model description and preliminary tests over multiple CORDEX domains. Clim. Res. 2012, 52, 7-29. [CrossRef]

34. INSMET (Instituto Nacional de Meteorología de Cuba). Base de Datos de Factores Climáticos Comprendidos en el Período 1980-2007; Informe Interno Instituto Nacional de Meteorología de Cuba: La Habana, Cuba, 2012.

35. Arnold, J.G.; Srinivasan, R.; Muttiah, R.S.; Williams, J.R. Large area hydrologic modeling and assessment-Part 1: Model development. J. Am. Water Res. Assoc. 1998, 34, 73-89. [CrossRef]

36. Neitsch, S.L.; Arnold, J.G.; Kiniry, J.R.; Williams, J.R. Soil and Water Assessment Tool 469 Theoretical Documentation, Version 2009; Texas Water Resources Institute: College Station, TX, USA, 2011.

37. U.S. Department of Agriculture-Soil Conservation Service. National Engineering Handbook Section 4 Hydrology; U.S. Department of Agriculture: Washington, DC, USA, 1972.

38. Williams, J.R. Flood Routing with variable travel time of variable storage coefficients. Trans. ASAE 1969, 12, 100-103. [CrossRef] 
39. Sloan, P.G.; Moore, I.D. Modeling subsurface stormflow on steeply sloping forested watersheds. Water Res. 1984, 20, 1815-1822. [CrossRef]

40. Hargreaves, G.H.; Samani, Z.A. Reference crop evapotranspiration from temperature. Appl. Eng. Agric. 1985, 1, 96-99. [CrossRef]

41. Winchell, M.; Srinivasan, R.; Di Luzio, M.; Arnold, J.G. ArcSWAT Interface for 521 SWAT2012 User's Guide; Blackland Research and Extension Center: Temple, TX, USA, 2013; Volume 522, pp. 439-464.

42. Agencia Medio Ambiente (AMA). Lineamientos Metodológicos para la Realización de los Estudios de Peligro, Vulnerabilidad y Riesgos de Desastres de Inundación por Penetraciones del mar, Inundación por Intensas Lluvias y Afectaciones por Fuertes Vientos, Cuba; Informe interno, Ministerio de Ciencia, Tecnología y Medio Ambiente (CITMA): La Habana, Cuba, 2007.

43. Food and Agriculture Organization of the United Nations (FAO). The Digital Soil Map of the World and Derived Soil 25 Properties, Version 3.6; Land and Water Digital Media Series 2; FAO: Rome, Italy, 2006.

44. Heuvelmans, G.; Muys, B.; Feyen, J. Evaluation of hydrological model parameter transferability for simulating the impact of land use on catchment hydrology. Phys. Chem. Earth 2004, 29, 739-747. [CrossRef]

45. Van Griensven, A. Sensitivity, Auto-Calibration, Uncertainty and Model Evaluation in SWAT 2005; UNESCO-IHE: Delft, The Netherlands, 2005.

46. Abbaspour, K. SWAT-CUP2: SWAT Calibration and Uncertainty Programs: A Pser Manual, Eawag; Swiss Federal Institute of Aquatic Science and Technology: Duebendorf, Switzerland, 2008.

47. Nash, J.E.; Sutcliff, J.V. River flow forecasting through conceptual models, part I-A discussion of principles. J. Hydrol. 1970, 10, 282-290. [CrossRef]

48. Moriasi, D.N.; Arnold, J.G.; Van Liew, M.W.; Bingner, R.L.; Harem, R.D.; Veith, T.L. Model evaluation guidelines for systematic quantification of accuracy in watershed simulations. Trans. ASABE 2007, 50, 850-900. [CrossRef]

49. Van Liew, M.W.; Arnold, J.G.; Bosch, D.D. Problems and potential of autocalibrating a hydrologic model. Trans. Am. Soc. Agric. 2005, 48, 1025-1040. [CrossRef]

50. Giorgi, F.; Marinucci, M.R.; Bates, G.T. Development of a second generation regional climate model (REGCM2). Part I: Boundary layer and radiative transfer processes. Mon. Weather Rev. 1993, 121, 2794-2813. [CrossRef]

51. Pal, J.S.; Giorgi, F.; Bi, X.; Elguindi, N.; Solmon, F.; Gao, X.; Francisco, R.; Zakey, A.; Winter, J.; Ashfaq, M.; et al. A Regional climate modeling for the developing world: The ICTP RegCM3 and RegCNET. Bull. Am. Meteorol. Soc. 2007, 88, 1395-1409. [CrossRef]

52. Emanuel, K. A scheme for representing cumulus convection in large-scale models. J. Atmos. Sci. 1991, 48, 2313-2335. [CrossRef]

53. Grell, G.A. Prognostic evaluation of assumptions used by cumulus parameterizations. Mon. Weather Rev. 1993, 21, 764-787. [CrossRef]

54. Oleson, K.W.; Niu, G.Y.; Yang, Z.L.; Lawrence, D. Improvements to the community land model and their impact on the hydrological cycle. J. Geophys. Res. 2008, 113, 2005-2012. [CrossRef]

55. Fuentes-Franco, R.; Coppola, E.; Giorgi, F.; Graef, F.; Pavía, E.G. Assessment of RegCM4 simulated inter-annual variability and daily-scale statistics of temperature and precipitation over Mexico. Clim. Dyn. 2014, 42, 629-647. [CrossRef]

56. Fuentes-Franco, R.; Coppola, E.; Giorgi, F.; Pavia, E.; Diro, G.T.; Graef, F. Inter-annual variability of precipitation over Southern Mexico and Central America and its relationship to sea surface temperature from a set of future projections from CMIP5 GCMs and RegCM4 CORDEX simulations. Clim. Dyn. 2015, 45, 425-440. [CrossRef]

57. Taylor, M.A.; Clarke, L.A.; Centella, A.; Benzanilla, A.; Stephenson, T.; Jones, J.J.; Campbell, D.; Vichot, A.; Charlery, J. Future Caribbean Climates in a World of Rising Temperatures: The 1.5 vs 2.0 Dilemma. J. Int. Climatol. 2018, 31, 2907-2926. [CrossRef]

58. New, M.; Hulme, M.; Jones, P.D. Representing twentieth century space-time climate variability. Part 2: Development of 1901-96 monthly grids of terrestrial surface climate. J. Clim. 2000, 13, 2217-2238. [CrossRef]

59. Taylor, K.E.; Stouffer, R.J.; Meehl, A. An Overview of CMIP5 and the Experiment Desing. Am. Meteorol. Soc. 2012, 93, 485-498. [CrossRef]

60. Lelis, T.A.; Calijuri, M.L. Modelagem hidrossedimentológica de bacia hidrográfica na região sudeste do Brasil, utilizando o SWAT. Int. J. Appl. Sci. 2010, 5, 158-174. [CrossRef] 
61. Guse, B.; Reusser, D.E.; Fohrer, N. How to improve the representation of hydrological processes in SWAT for a lowland catchment-Temporal analysis of parameter sensitivity and model performance. Hydrol. Proc. 2014, 28, 2651-2670. [CrossRef]

62. White, K.L.; Chaubey, I. Sensitivity analysis, calibration, validations for a multisite and multivariable SWAT. J. Am. Water Res. Assoc. 2005, 41, 1077-1089. [CrossRef]

63. Zhang, A.J.; Zheng, C.M.; Wang, S.; Yao, Y.Y. Analysis of streamflow variations in the Heihe River Basin, northwest China: Trends, abrupt changes, driving factors and ecological influences. J. Hydrol. 2015, 3, 106-124. [CrossRef]

64. Feyereisen, G.W.; Strickland, T.C.; Bosch, D.D.; Sullivan, D.G. Evaluation of SWAT manual calibration and input parameter sensitivity in the little river watershed. Trans. ASABE 2007, 50, 843-855. [CrossRef]

65. Gebremariam, S.Y.; Martin, J.F.; DeMarchi, C.; Bosch, N.S.; Confesor, R.; Ludsin, S.A. A comprehensive approach to evaluating watershed models for predicting river flow regimes critical to downstream ecosystem services. Environ. Mod. Softw. 2014, 61, 121-134. [CrossRef]

66. Andrade, M.A.; Mello, C.R.; Beskow, S. Simulacão hidrológica em uma bacia hidrográfica representativa dos Latossolos na região Alto Rio Grande. Eng. Agríc. Ambient. 2013, 17, 69-76. [CrossRef]

67. Tripathi, M.P.; Panda, R.K.; Raghuwanshi, N.S. Calibration and Validation of SWAT Model for Predicting Runoff and Sediment Yield of a Small Watershed in India. J. Agric. Eng. 2003, 12, 95-118.

68. Niraula, R.; Meixner, T.; Norman, L.M. Determining the importance of model calibration for forecasting absolute/relative changes in streamflow from LULC and climate changes. J. Hydrol. 2015, 522, 439-451. [CrossRef]

69. Marhaento, H.; Booij, M.J.; Rientjes, T.; Hoekstra, A.Y. Attribution of changes in the water balance of a tropical catchment to land use change using the SWAT model. Hydrol. Proc. 2017, 31, 2029-2040. [CrossRef]

70. Taylor, M.A.; Centella, A.; Charlery, J.; Borrajero, I.; Bezanilla, A.; Campbell, J.D. Glimpses of the Future: A Briefing from the PRECIS Caribbean Climate Change Project; Caribbean Community Climate Change Centre: Belmopan, Belize, 2007.

71. Christensen, J.H.; Hewitson, B.; Busuioc, A. Regional climate projections, in Climate Change 2007: The Physical Science Basis. Contribution of Working Group I to the Fourth Assessment Report of the Intergovernmental Panel on Climate Change, Chap. Agenda 2007, 11, 235-336.

72. Rauscher, S.A.; Giorgi, F.; Diffenbaugh, N.S.; Seth, A. Extension and intensification of the Meso-American midsummer drought in the twenty-first century. Clim. Dyn. 2008, 31, 551-571. [CrossRef]

73. Álvarez-Adán, A.; Febles, G.; Díaz, L. La variabilidad climática y análisis de contextos futuros de cambio climático en la cuenca del Cauto. Ciencias de la Tierra y el Espacio 2015, 16, 107-116.

74. Donk, P.; Van Uytven, E.; Willems, P.; Taylor, M. Assessment of the potential implications of a $1.5^{\circ} \mathrm{C}$ versus higher global temperature rise for the Afobaka hydropower scheme in Suriname. J. Reg. Environ. Chang. 2018. [CrossRef]

75. Arnell, N.W. Climate change and global water resources: SRES emissions and socio-economic scenarios. Glob. Environ. Chang. 2004, 14, 31-52. [CrossRef]

76. Massah, A.R.; Morid, S. The Impacts of Climate Change on Water Resources and Agricultural Production. J. Water Res. 2007, 1, 40-47.

77. Chien, H.; Yeh, P.J.F.; Knouft, J.H. Modeling the potential impacts of climate change on streamflow in agricultural watersheds of the Midwestern United States. J. Hydrol. 2013, 491, 73-88. [CrossRef]

78. Kwadijk, J. The Impact of Climate Change on the Discharge of the River. Ph.D. Thesis, Royal Dutch Geographical Society, Dutch, The Netherlands, 1993.

79. Milly, P. Climate, interseasonal storage of soil water, and the annual water balance. Adv. Water Res. 1994, 17, 19-24. [CrossRef]

80. Thapaa, B.R.; Ishidairaa, H.; Prasad, V.; Man, M. A multi-model approach for analyzing water balancedynamics in Kathmandu Valley, Nepal. J. Hydrol. Reg. Stud. 2016, 9, 149-162. [CrossRef]

81. Stehr, A.; Debels, P.; Romero, F.; Alcayaga, H. Hydrological modelling with SWAT under conditions of limited data availability: Evaluation of results from a Chilean case study. J. Hydrol. Sci. 2010, 53, 588-601. [CrossRef]

82. Merz, R.; Parajka, J.; Bloeschl, G. Time stability of catchment model parameters: Implications for climate impact analyses. Water Resour. Res. 2011, 47, W02531. [CrossRef] 
83. Fukunaga, D.; Avelino, R.; Zanety, S.S.; Olivera, T.L.; Costa, M.A. Application of the SWAT hydrologic model to a tropical watershed at Brazil. Catena 2014, 125, 206-213. [CrossRef]

84. Pierini, N.; Vivoni, E.; Robles-Morua, A.; Scott, R.; Nearing, M. Using observations and a distributed hydrologic model to explore runoff thresholds linked with mesquite encroachment in the Sonoran Desert. Water Resour. Res. 2014, 50, 8191-8215.

85. Qiao, L.; Zou, C.; Will, R.; Stebler, E. Calibration of SWAT model for woody plant encroachment using paired experimental watershed data. J. Hydrol. 2015, 523, 231-239. [CrossRef]

86. Robles-Morua, A.; Che, D.; Mayer, A.S.; Vivoni, E.R. Hydrological assessment of proposed reservoirs in the Sonora River Basin, Mexico, under historical and future climate scenarios. J. Hydrol. Sci. 2014, 60, 50-66. [CrossRef]

87. Ehret, U.; Zehe, E.; Wulfmeyer, V.; Warrach-Sagi, V.; Liebert, J. Should we apply bias correction to global and regional climate model data? Hydrol. Earth Syst. Sci. 2012, 16, 3391-3404. [CrossRef]

2018 by the authors. Licensee MDPI, Basel, Switzerland. This article is an open access article distributed under the terms and conditions of the Creative Commons Attribution (CC BY) license (http:/ / creativecommons.org/licenses/by/4.0/). 